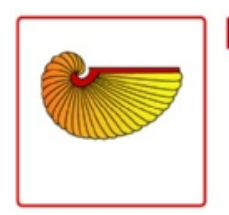

FRONTIERS IN ZOOLOGY

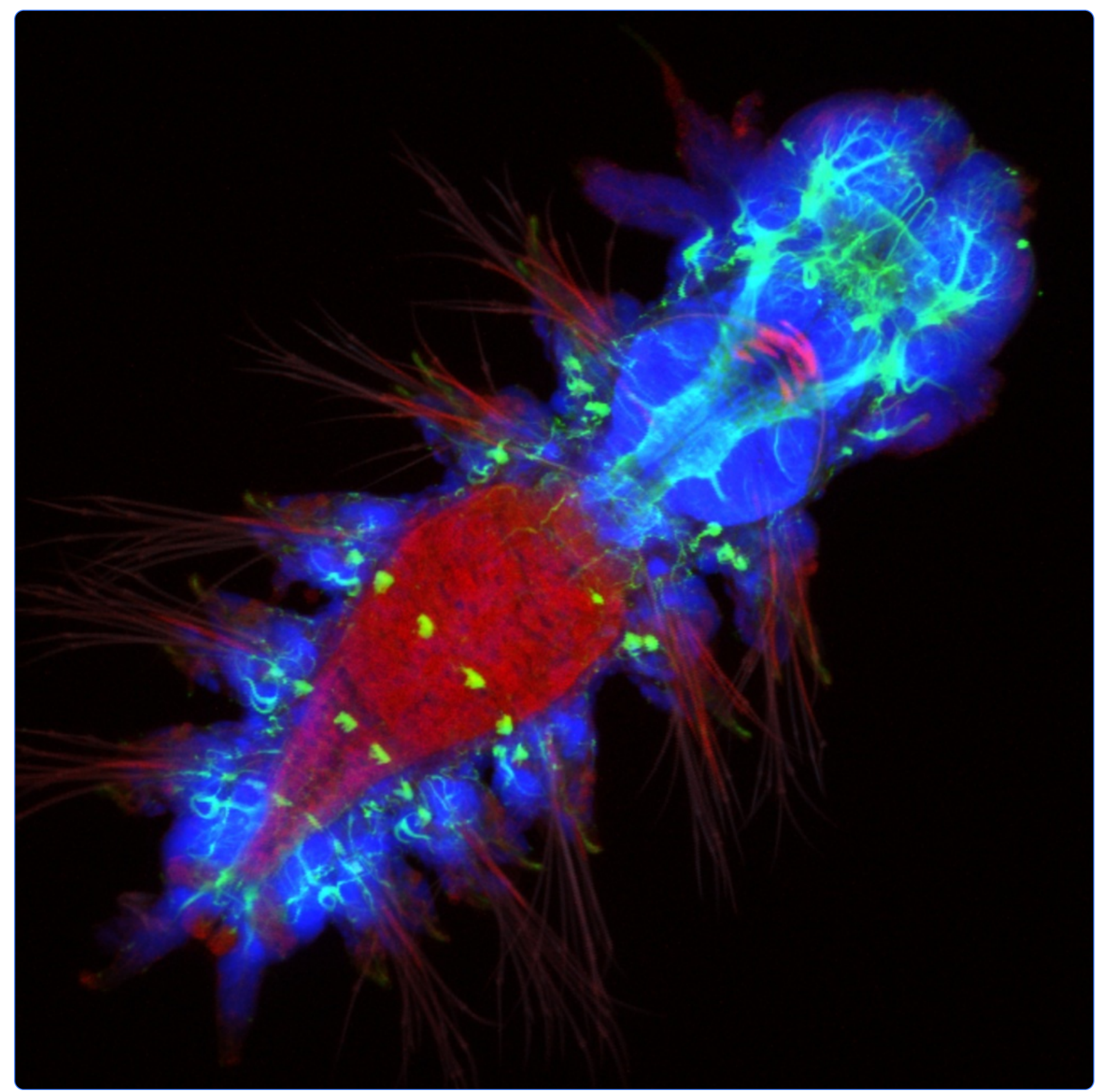

Myoinhibitory peptide regulates feeding in the marine annelid Platynereis

Williams et al.

C Biomed Central 


\title{
Myoinhibitory peptide regulates feeding in the marine annelid Platynereis
}

\author{
Elizabeth A Williams, Markus Conzelmann and Gáspár Jékely
}

\begin{abstract}
Background: During larval settlement and metamorphosis, marine invertebrates undergo changes in habitat, morphology, behavior and physiology. This change between life-cycle stages is often associated with a change in diet or a transition between a non-feeding and a feeding form. How larvae regulate changes in feeding during this life-cycle transition is not well understood. Neuropeptides are known to regulate several aspects of feeding, such as food search, ingestion and digestion. The marine annelid Platynereis dumerilii has a complex life cycle with a pelagic non-feeding larval stage and a benthic feeding postlarval stage, linked by the process of settlement. The conserved neuropeptide myoinhibitory peptide (MIP) is a key regulator of larval settlement behavior in Platynereis. Whether MIP also regulates the initiation of feeding, another aspect of the pelagic-to-benthic transition in Platynereis, is currently unknown.

Results: Here, we explore the contribution of MIP to the regulation of feeding behavior in settled Platynereis postlarvae. We find that in addition to expression in the brain, MIP is expressed in the gut of developing larvae in sensory neurons that densely innervate the hindgut, the foregut, and the midgut. Activating MIP signaling by synthetic neuropeptide addition causes increased gut peristalsis and more frequent pharynx extensions leading to increased food intake. Conversely, morpholino-mediated knockdown of MIP expression inhibits feeding. In the long-term, treatment of Platynereis postlarvae with synthetic MIP increases growth rate and results in earlier cephalic metamorphosis.

Conclusions: Our results show that MIP activates ingestion and gut peristalsis in Platynereis postlarvae. MIP is expressed in enteroendocrine cells of the digestive system suggesting that following larval settlement, feeding may be initiated by a direct sensory-neurosecretory mechanism. This is similar to the mechanism by which MIP induces larval settlement. The pleiotropic roles of MIP may thus have evolved by redeploying the same signaling mechanism in different aspects of a life-cycle transition.
\end{abstract}

\section{Background}

Many organisms have a complex life cycle consisting of distinct stages that differ in form, physiology, behavior and habitat. Among benthic marine invertebrates, a common life cycle strategy, the biphasic life cycle, consists of a free-swimming larva that settles to the ocean floor and undergoes metamorphosis to a bottom-dwelling adult [1]. Marine invertebrate larval settlement is often coupled to the initiation of feeding or a change in diet [2]. These behavioral, physiological and morphological changes have to be tightly coordinated for the successful transition to a benthic life style. Knowledge of how this transition is

\footnotetext{
* Correspondence: gaspar.jekely@tuebingen.mpg.de

Max Planck Institute for Developmental Biology, Spemannstrasse 35,

Tübingen 72076, Germany
}

C Biomed Central

(C) 2015 Williams et al.; licensee BioMed Central. This is an Open Access article distributed under the terms of the Creative Commons Attribution License (http://creativecommons.org/licenses/by/4.0), which permits unrestricted use, distribution, and reproduction in any medium, provided the original work is properly credited. The Creative Commons Public Domain Dedication waiver (http://creativecommons.org/publicdomain/zero/1.0/) applies to the data made available in this article unless otherwise stated.

regulated is important for understanding population structure in the ocean, life-history evolution, and how the environment influences animal life cycles [3-8].

The marine annelid Platynereis dumerilii has recently proven to be a useful marine invertebrate model for studying the molecular details of marine larval behavior, including settlement [9-12]. Platynereis has a biphasic life cycle with free-swimming, non-feeding larval (trochophore and nectochaete) stages and bottom-dwelling, feeding postlarval, juvenile and adult stages [13]. Larval settlement is followed by a period of growth and feeding, during which juvenile Platynereis add additional posterior segments. Cephalic metamorphosis, in which the first pair of parapodia are transformed into a second pair of tentacular cirri 
on the head, occurs after the juveniles have begun to add their sixth posterior segment [13-16].

Recently, we identified myoinhibitory peptide (MIP) as an inducer of rapid larval settlement behavior in Platynereis [11]. MIP is expressed in anterior chemosensoryneurosecretory neurons of the larva. Exogenous application of MIP inhibits the activity of the locomotor cilia, resulting in rapid sinking, and induces sustained contact with the substrate. Platynereis MIP belongs to an ancient neuropeptide family of Wamides, which are characterized by their amidated C-terminal tryptophan residue preceded by a small aliphatic residue $[11,17]$. Wamides are widespread among eumetazoans, except deuterostomes, and recently emerged as conserved regulators of life-cycle transitions [18]. For example, in some insects, MIP (also known as prothoracicostatic peptide (PTSP) or allatostatinB (AST-B)) regulates ecdysone [19-21] and juvenile hormone levels [22], potentially influencing the timing of larval ecdysis and pupation. In cnidarians, including some corals and hydrozoans, GLWamide (also called metamorphosin) is known to induce larval settlement and metamorphosis [23-25].

How changes in feeding are regulated during marine life-cycle transitions is less well understood. Many neuropeptides are known to have roles in regulating different aspects of feeding [26-28]. MIPs/Wamides are also pleiotropic [29-35] and regulate aspects of feeding and gut muscle activity in some insects and cnidarians. The first MIP described had a myoinhibitory function on adult locust hindgut [36]. In several insects, MIP is expressed in the adult stage and can suppress muscle contractions of the hindgut [36-40]. MIP is also expressed in the stomatogastric nervous system of the adult crab, Cancer borealis, where it decreases the frequency of pyloric rhythm $[41,42]$. In addition, cnidarian GLWamide increases myoactivity in both hydra and sea anemone polyps, potentially influencing feeding $[43,44]$. Although none of these studies directly quantified feeding in the whole organism, MIP is a strong candidate for the regulation of feeding during marine life-cycle transitions.

Here, we study the expression and function of MIP in Platynereis during late larval (3-6 days) and early juvenile development (6-30 days). We found MIP expression in sensory neurons of the gut of 6 days and older Platynereis. We used both peptide-soaking and morpholino-mediated knockdown approaches to establish a role for MIP in the regulation of postlarval feeding and gut peristalsis. MIP treatment also resulted in faster juvenile growth, probably as a consequence of increased food ingestion and gut movement. Our results establish MIP as a pleiotropic neuropeptide in Platynereis that links behavioral and physiological components of a lifecycle transition.

\section{Results}

Platynereis MIP is expressed in the brain and gut of postlarvae, juveniles and adults

Expression profiling of the MIP precursor gene by RNA in situ hybridization showed that MIP is expressed during both larval and postlarval development and continues to be expressed after cephalic metamorphosis, in the early adult stage (Figure 1A-C, G-H; Additional file 1). At 6 days and older, MIP is expressed in both the median brain and the trunk nervous system, in paired cells and also in single cells closer to the larval midline. We also found MIP expression in the digestive system, in the fore-, midand hindgut. The different regions of the gut are delineated by the differential expression patterns of Platynereis digestive system marker genes (Figure 1D, I; discussed below). The MIP-expressing cells in the gut have sensory dendrites that project toward the lumen of the gut (Figure 1B-C; Additional files 2, 3). In some of these dendrites we could even detect the MIP RNA in situ signal, allowing the unambiguous assignment of these acetylated tubulin-positive cellular projections to the MIP-expressing cells (Additional file 3).

In addition to $M I P$, we also attempted to characterize the expression of the MIP receptor in $6 \mathrm{dpf}$ and older larvae. We previously described the expression of the MIP receptor in the head of $2 \mathrm{dpf}$ Platynereis larvae [11], however, in older larvae and postlarvae, the levels of MIP receptor expression proved too low to detect reliably with our RNA in situ hybridization method. The low expression of the Platynereis MIP receptor is typical of most G protein-coupled receptor expression levels [45].

Immunostaining with an antibody against Platynereis MIP showed that in addition to the neurosecretory plexus of the brain, MIP peptide is transported throughout the ventral nerve cord. At 6 days post fertilization (dpf), MIP-expressing neurons in the digestive system innervate both the foregut and hindgut (Figure 1E, F). As larvae progress from 3 to $6 \mathrm{dpf}$, during which time the digestive system develops, MIP expression first emerges in the developing hindgut at $4 \mathrm{dpf}$, followed by the expression in the foregut at $6 \mathrm{dpf}$ (Additional file 4A-L). By one month, MIP-expressing cells densely innervate the entire length of the gut, forming a nerve-net. Using an antibody against the conserved $\mathrm{C}$-amidated dipeptide VWamide [11], we found similar immunolabeling in the brain, ventral nerve cord and gut of larvae of Capitella teleta, a distantly related annelid species [46] (Additional file 4M-P).

By combining phalloidin staining and MIP immunostaining in Platynereis 1 month post fertilization (1 mpf), we could assess the location of MIP-expressing neurons in the gut in relation to the digestive system musculature. In the foregut and in the sphincter muscle that separates foregut from hindgut, MIP-expressing neurons are intermingled with the muscle tissue of the pharynx and 


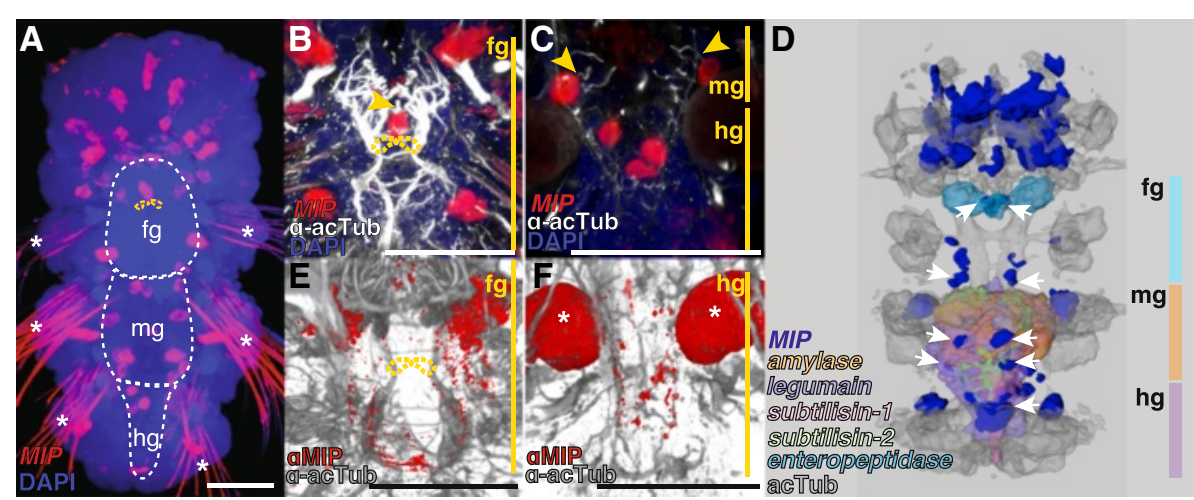

G $\quad 6 \mathrm{dpf} \mathrm{VNC/ventral}$

H $6 \mathrm{dpf}$ gut/dorsal âTulb

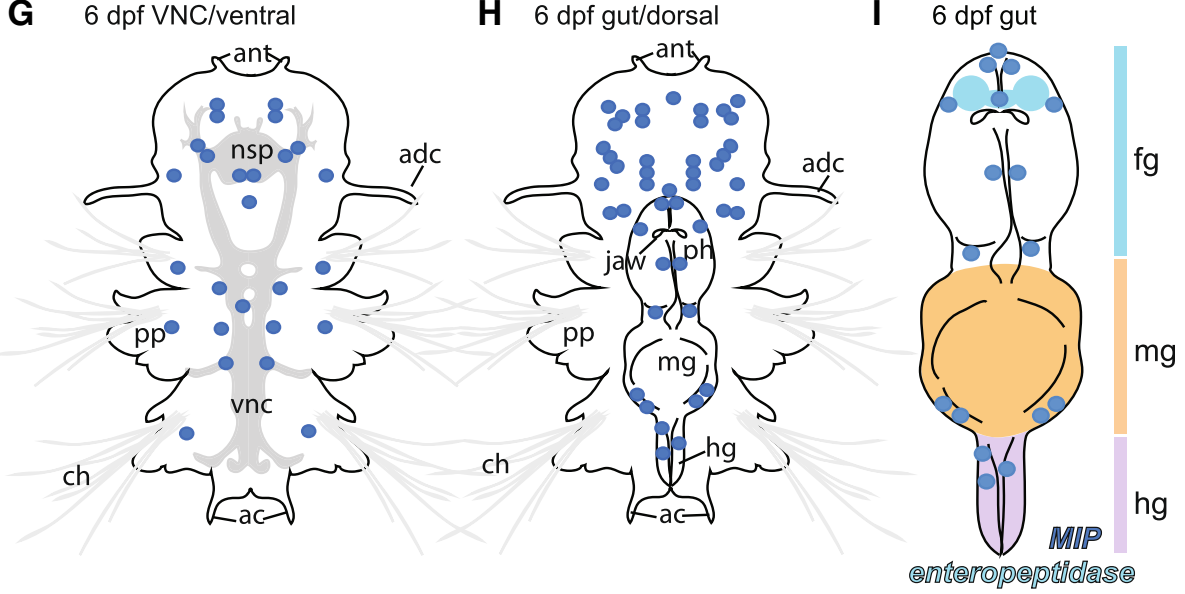

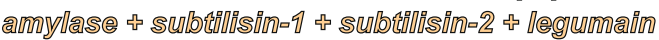

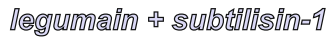

Figure 1 MIP is expressed in the digestive system of 6 dpf Platynereis. (A) Whole-mount RNA in situ hybridization (WMISH) for the Platynereis MIP precursor (red) counterstained with DAPI nuclear stain (blue). Ventral view of 6 dpf Platynereis with the image stacks corresponding to the ventral nerve cord (VNC) region not included in the maximal projection (outlined with white dashed line). White asterisks indicate background reflection from chaetae. (B, C) Close-up WMISH for the Platynereis MIP precursor (red) counterstained for acetylated tubulin (a-acTub) (white) and DAPI nuclear stain (blue). Yellow arrowheads indicate sensory dendrites of MIP-expressing cells. (B) Ventral view of the foregut. (C) Ventral view of the midgut and hindgut. (D) Dorsal view of surface representation of average MIP precursor expression domains registered to a $6 \mathrm{dpf}$ nuclear stain reference template. Expression domains of alpha-amylase, legumain protease precursor, subtilisin-1, subtilisin-2 and enteropeptidase are included as digestive system markers. White arrows indicate areas of MIP expression associated with the digestive system. (E, F) Immunostaining with Platynereis MIP antibody (red) counterstained with acetylated tubulin (grey) at $6 \mathrm{dpf}$, with the image stacks corresponding to the VNC region not included in the maximum projection to show only the digestive system. (E) Ventral view of foregut. (F) Ventral view of hindgut. White asterisks indicate background reflection from spinning glands. (G-I) Schematic representation of MIP precursor expression in 6 dpf Platynereis. (G) Ventral side. (H) Dorsal side. (I) MIP expression relative to expression of digestive system marker genes in the gut. In (A, B, E), yellow dashed lines indicate the jaws. Scale bars: 50 MM. Abbreviations: fg, foregut; mg, midgut; hg, hindgut; ant, antenna; nsp, neurosecretory plexus; adc, anterior dorsal cirrus; pp, parapodia; vnc, ventral nerve cord; ch, chaetae; ac, anal cirrus; ph, pharynx.

sphincter (Figure 2A-C). In the mid- and hindgut, MIPexpressing neurons sit in the inner epithelial cell layer underlying the smooth muscles of the gut (Figure 2D-K). The axons of the MIP-expressing cells in the mid- and hind-gut of 1 month post fertilization (mpf) Platynereis run parallel to and just beneath the muscle fibers of both circular and longitudinal smooth muscles (Figure 2I-K). The spatial expression patterns of Platynereis MIP and MIP peptide suggest a potential role for MIP signaling in feeding and digestion during larval and early juvenile stages of the life cycle.

\section{Characterization of normal gut development and the initiation of feeding in postlarvae}

At $6 \mathrm{dpf}$ Platynereis postlarvae have a through gut with clearly recognizable fore-, mid- and hindgut regions (Figure 1). The foregut contains the muscular and extendable pharynx with the jaws and salivary glands (Additional file 2). Phyllodocid polychaetes, such as Platynereis, have an axial muscular pharynx consisting of circular, longitudinal and radial muscle fibers, which allow for complex sucking and swallowing movements $[47,48]$. The foregutmidgut boundary is marked by the presence of a sphincter 


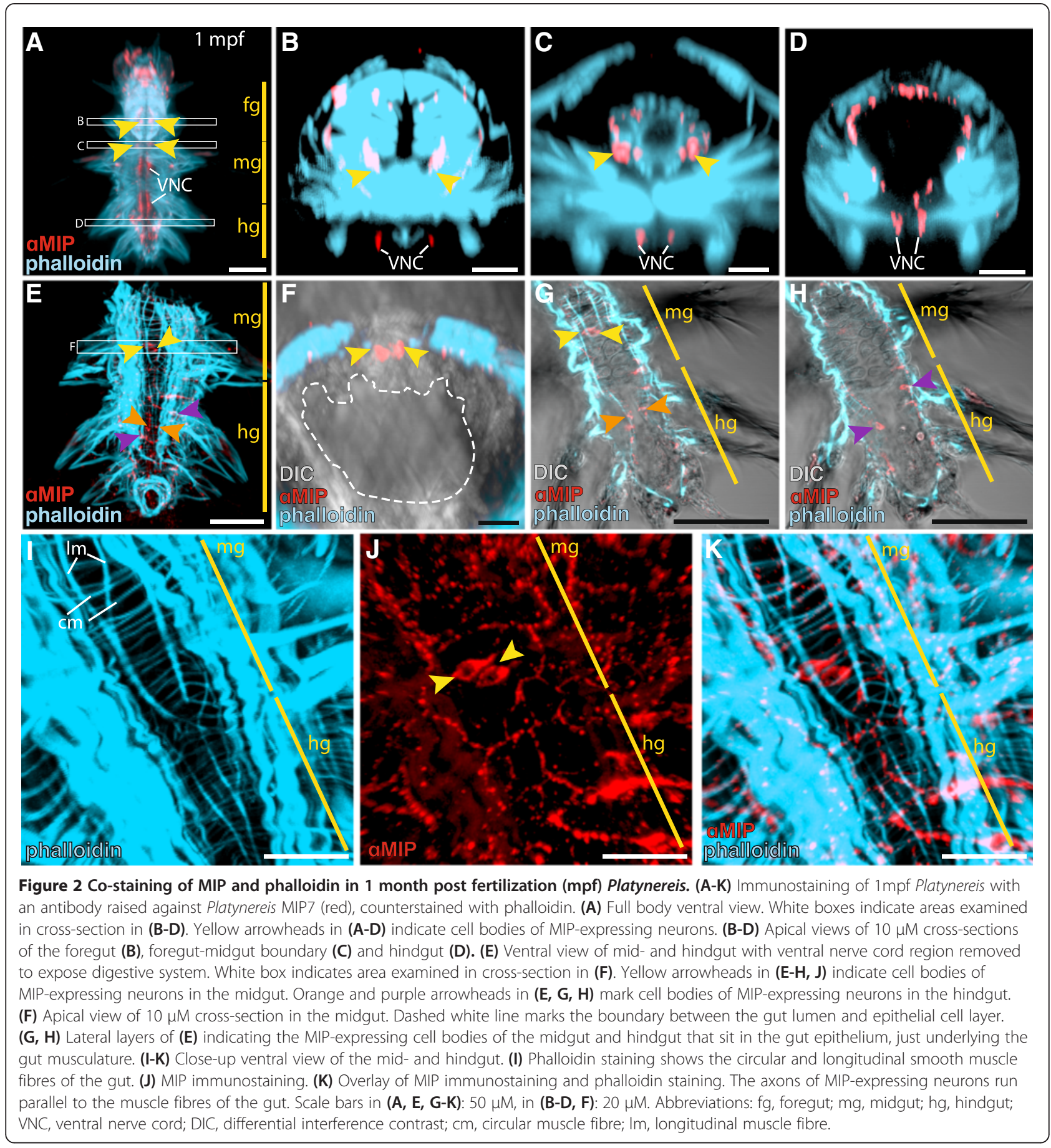

muscle. This muscle showed regular contractions in larvae expressing a genetically encoded calcium indicator GCaMP6 (Additional file 5). The broad midgut does not show regionalization and is followed by a short and narrow hindgut.

To gain insight into the morphology and maturation of the Platynereis digestive system, we carried out wholemount RNA in situ hybridization on $6 \mathrm{dpf}, 14 \mathrm{dpf}$ and 1 mpf Platynereis with marker genes selected from an ongoing broad RNA in situ hybridization screen, based on their expression in the digestive system at $6 \mathrm{dpf}$. The digestive system marker genes were identified through domain conservation, reciprocal BLAST and phylogenetic analyses as: extracellular digestive enzymes, peptidases subtilisin-1 and subtilisin-2 (Peptidase_S8; Pfam domain: PF00082), the protease enteropeptidase, responsible for the activation of proteolytic enzymes [49], the polysaccharidedigesting enzyme alpha-amylase, and the intracellular 
digestive enzyme legumain protease precursor (Figure 1D, I; Additional files 6, 7, 8). Alpha-amylase and subtilisin-1 expression was restricted to the midgut at $6 \mathrm{dpf}$, but expanded to mid- and hindgut at $14 \mathrm{dpf}$ and $1 \mathrm{mpf}$. Legumain protease precursor was constantly expressed in both mid- and hindgut from $6 \mathrm{dpf}$ to $1 \mathrm{mpf}$, while subtilisin-2 expression was restricted to the midgut from $6 \mathrm{dpf}$ to 1 $\mathrm{mpf}$. Enteropeptidase was the only gene with expression in the foregut, including the salivary glands, at 6 and $14 \mathrm{dpf}$. At $1 \mathrm{mpf}$, enteropeptidase remained strongly expressed in the foregut, but expression also extended to the midand hindgut. Registration of these marker gene expression patterns [50] at $6 \mathrm{dpf}$ to a common nuclear stain reference scaffold, along with the average $6 \mathrm{dpf} M I P$ expression, highlighted the close association of MIP-expressing cells with the digestive system at this stage (Figure 1D; Additional file 9).

We also looked at the change in expression of these digestive system marker genes and MIP across the Platynereis life cycle in stage-specific RNA-seq datasets [51].
With the exception of legumain protease precursor, the expression of all digestive system marker genes was undetectable in non-feeding larval stages but sharply increased between 4 and $10 \mathrm{dpf}$ (Additional file 10). In accordance with a digestive function, these genes were strongly down-regulated in the adult non-feeding epitokes. MIP expression also increased sharply between 4 and $10 \mathrm{dpf}$, although it continued to be expressed in the non-feeding epitokes, suggesting further functional roles beyond feeding in Platynereis.

Following settlement, Platynereis larvae have been reported to begin feeding between $5-8 \mathrm{dpf}$, with considerable variation between individuals $[13,16]$. Due to this variability, we decided to document feeding initiation in our own laboratory culture (Figure 3A). We added Tetraselmis marina microalgae to the larval cultures and documented feeding based on chlorophyll fluorescence in the gut (Figure 4C). Most larvae initiated feeding between 6 and 7 dpf; by 8 dpf, nearly all larvae had started feeding (Figure 3A).
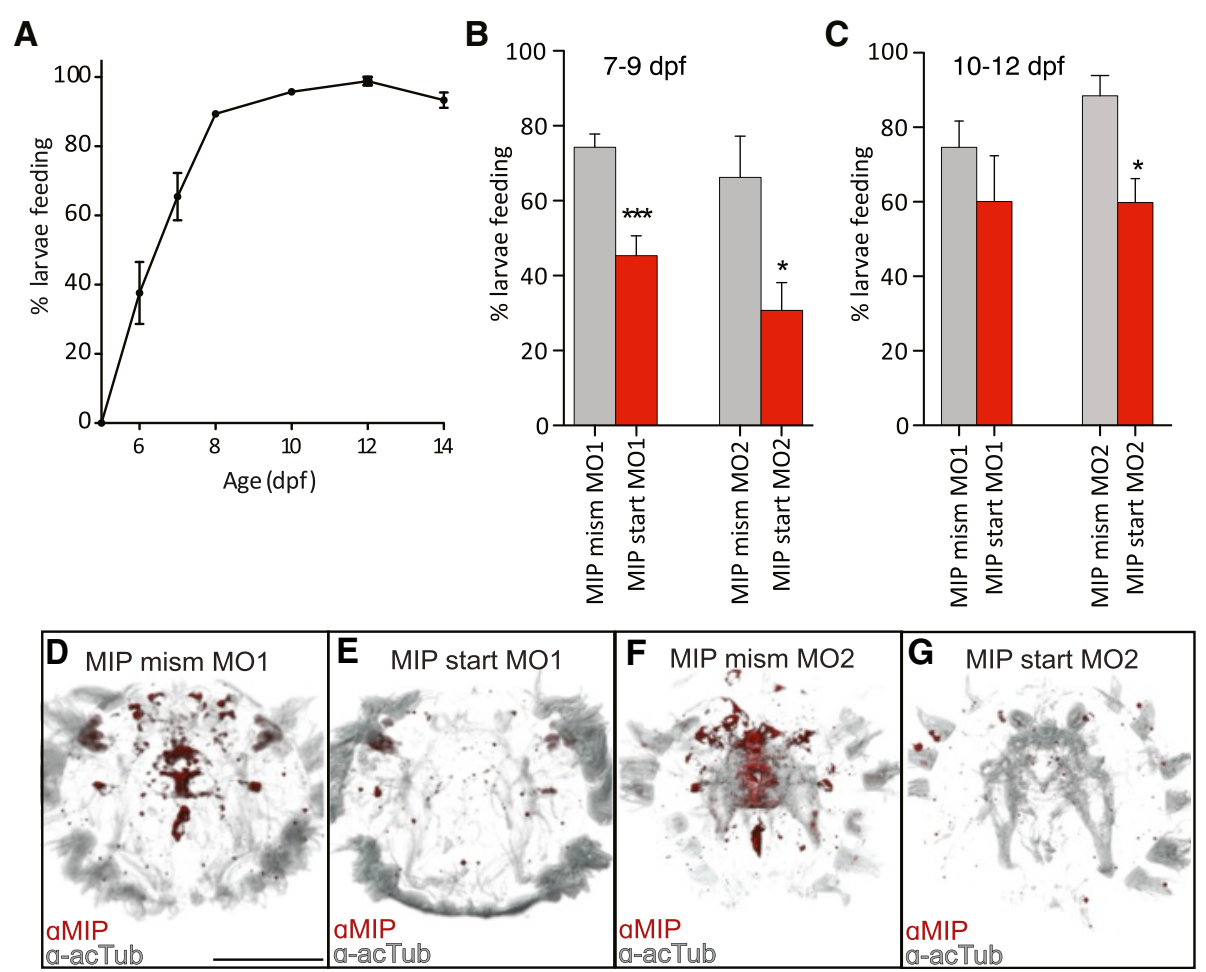

Figure 3 Feeding in control and MIP knockdown larvae. (A) Timecourse of initiation of feeding during Platynereis larval development. \% larvae feeding on Tetraselmis marina algae between $5-14 \mathrm{dpf}, \mathrm{n}=3 \times 30$ larvae. (B) \% larvae feeding at 7 - 9 dpf following injection of MIP mismatch ( $n=210$ larvae mismatch MO1, 118 larvae mismatch MO2) or start $(n=424$ larvae start MO1, 79 larvae start MO2) morpholinos (C) $\%$ larvae feeding at $10-12 \mathrm{dpf}$ following injection of MIP mismatch ( $n=115$ larvae mismatch MO1, 72 larvae mismatch MO2) and start $(n=185$ larvae start MO1, 62 larvae start MO2) morpholinos. Data in (A-C) are shown as mean +/- s.e.m. p-value cut-offs based on unpaired t-test: *** $<0.001 ; * * 0.01 ; * 0.05$. (D-G) Anterior view of 6 dpf Platynereis injected with MIP mismatch or start morpholinos and immunostained with Platynereis MIP antibody (red) counterstained with acetylated tubulin (grey). Identical confocal microscopy and image processing parameters were applied to all images. Scale bar: $100 \mu \mathrm{m}$. Abbreviations: mism, mismatch; MO, morpholino; a-acTub, anti acetylated tubulin. 


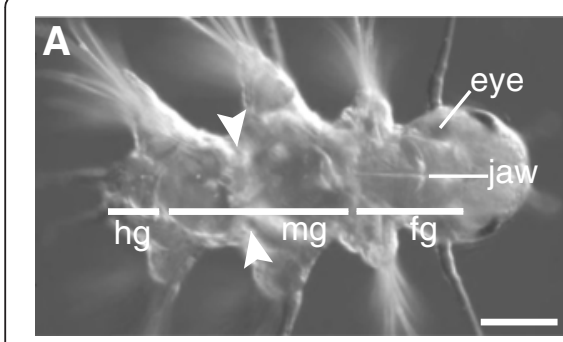

D

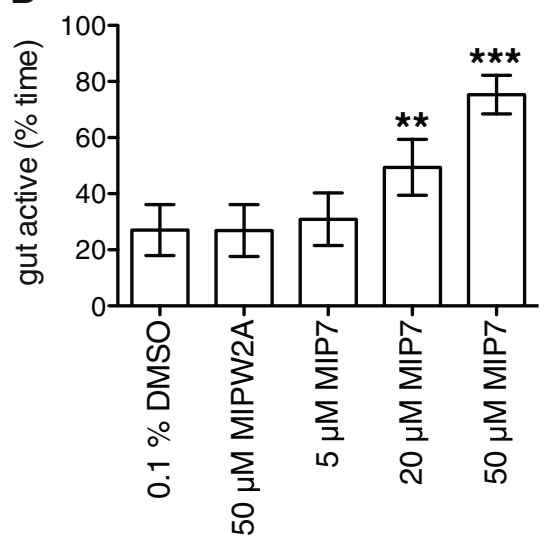

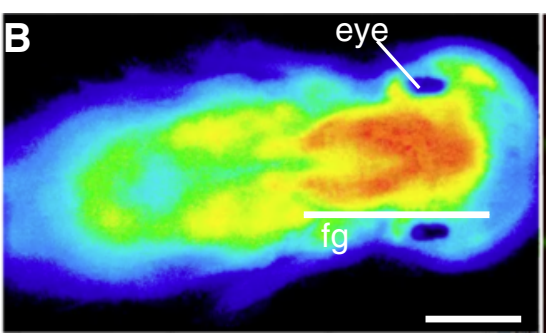

E

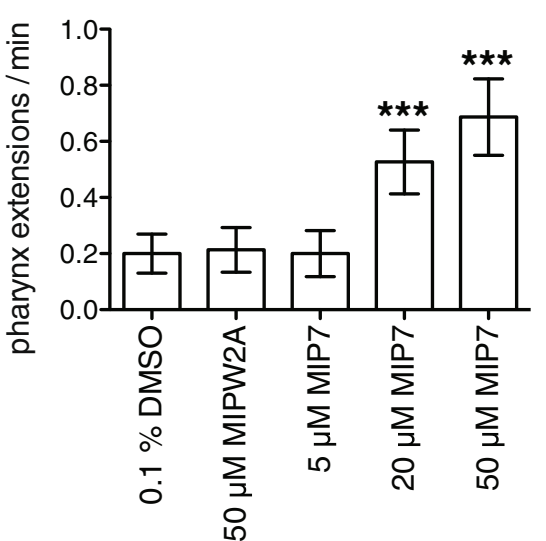

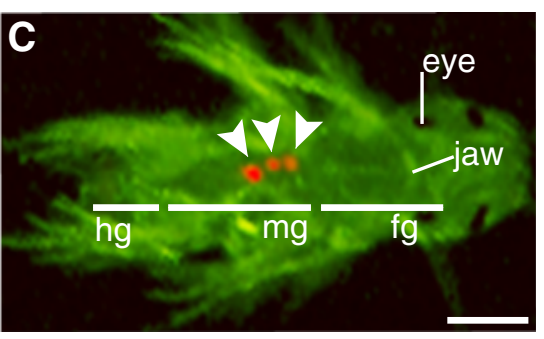

$\mathbf{F}$

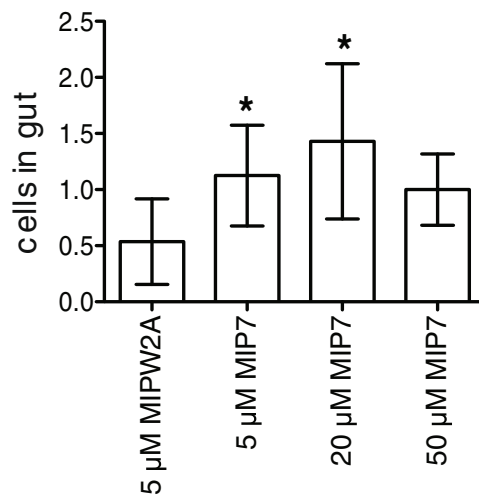

Figure 4 Synthetic MIP treatment increases gut peristalsis, pharynx extension and ingestion in Platynereis. (A) Differential interference contrast micrograph of $6.5 \mathrm{dpf}$ Platynereis. White arrowheads indicate muscular contraction in the gut. (B) Calcium-imaging with GCaMP6 in 6.5 dpf Platynereis highlights muscular pharynx extension in the foregut. (C) Fluorescent micrograph of 7 dpf Platynereis with AF488 filter. White arrowheads indicate autofluorescent Tetraselmis cells in the gut. All images are dorsal views, with head to the right. (D) Gut activity as percentage of time in MIP-treated versus control 6.5 dpf Platynereis. (E) Number of pharynx extensions per minute in MIP-treated versus control 6.5 dpf Platynereis. (F) Number of Tetraselmis marina algae cells eaten per larvae in 30 min in MIP-treated versus control 7 dpf Platynereis. (D-F) Data are shown as mean +/- 95\% confidence interval, $n=60$ larvae. p-value cut-offs based on unpaired $t$-test: ${ }^{* * *}<0.001 ;{ }^{* *}<0.01 ;{ }^{*}<0.05$. MIPW2A is a control non-functional MIP peptide in which the two conserved tryptophan sites are substituted with alanines. Scale bars: 50 um. Abbreviations: hg, hindgut; mg, midgut; fg, foregut.

\section{Knockdown of MIP delays the initiation of feeding in Platynereis larvae}

To explore the function of MIP in the Platynereis digestive system, we employed morpholino microinjection to knockdown MIP expression. We used two different translation blocking morpholinos and two mismatch control morpholinos (Additional file 11). To test the effectiveness of MIP-knockdown, we immunostained knockdown and control larvae with an antibody against Platynereis MIP. We observed a strong reduction in MIP immunostaining in Platynereis MIP-knockdown larvae, but not in controls, up to at least $6 \mathrm{dpf}$ (Figure 3D-G, Additional file 12). These experiments confirmed that the MIP morpholinos were capable of strongly reducing MIP expression.

Next, we documented feeding in MIP-knockdown and control larvae. Similar to untreated larvae, most larvae injected with a control morpholino had initiated feeding between 7-9 dpf, whereas a significantly lower number of MIP-knockdown larvae had food in the gut at 7-9 dpf. This effect was still observed between 10-12 dpf (Figure 3B-C).

To rule out that the reduced feeding in MIP-knockdown larvae is due to a developmental delay, we compared the morphology of the nervous system of MIP-knockdown and control larvae. There were no detectable differences in the nervous system of control larvae and MIPknockdown larvae based on acetylated tubulin immunostainings at $6 \mathrm{dpf}$ (Figure 3D-G; Additional file 13). We also treated uninjected larvae at different ages between 24 hours post fertilization (hpf) and $5 \mathrm{dpf}$ with synthetic MIP peptide to see whether MIP-treated larvae initiate feeding sooner, indicating a potential developmental acceleration. MIP treatment did not significantly alter the timing of feeding initiation, even when food was available earlier than $5 \mathrm{dpf}$ (Additional file 14). These experiments indicate a critical physiological role for MIP in the initiation of feeding behaviour in Platynereis postlarvae.

\section{MIP treatment has a myostimulatory effect on the digestive system of Platynereis postlarvae}

In order to understand how the morpholino knockdown of MIP resulted in reduced larval feeding, we examined the effect of synthetic MIP treatment on postlarvae, focusing on the digestive system. Treatment of $6.5 \mathrm{dpf}$ postlarvae with synthetic MIP caused a significant increase in gut 
peristalsis (Figure 4A, D; Additional file 15). MIP-treated postlarvae also displayed increased rates of pharynx extension (Figure 4B, E; Additional file 16).

To determine whether these effects on gut and pharynx movement resulted in increased ingestion of algal cells in MIP-treated postlarvae, we then scored the number of algal cells consumed by MIP-treated versus control $7 \mathrm{dpf}$ postlarvae. Treatment with $5 \mu \mathrm{M}$ and $20 \mu \mathrm{M}$ MIP significantly increased postlarval algal cell consumption (Figure 4C, F; Additional file 17). Additionally, MIPtreated postlarvae have decreased locomotion, indicating a switch in the nervous system from a locomotory to a feeding program (Additional file 18). These results show that MIP up-regulates feeding activity and gut peristalsis.

\section{Long-term MIP treatment enhances growth in Platynereis postlarvae}

Given the effect of MIP on the digestive system and feeding in Platynereis postlarvae, we next investigated the long-term effects of MIP treatment on postlarval growth. At approximately two weeks of age, feeding Platynereis begin to add new posterior segments [13]. After the development of the $5^{\text {th }}$ segment, juveniles undergo cephalic metamorphosis, a morphogenetic process in which the first chaetigerous segment loses its chaetae, develops a pair of tentacular cirri and fuses with the head (Figure 5A-D). The timing of cephalic metamorphosis and the addition of new segments vary between individuals. Even juveniles cultured individually showed variation in the timing of posterior segment addition, with segment number varying between 4 and 8 segments at $34 \mathrm{dpf}$ (Additional file 19D). On a diet of Tetraselmis, the shortest interval for an individually-raised juvenile to develop an additional posterior segment was 4 days. The addition of new segments required that larvae begin to feed. Unfed larvae never develop beyond the 3-segmented stage (Additional file 19E). Growth in other nereid species depends on culture density [52-55]. We documented the growth of Platynereis juveniles cultured at different densities with excess food and determined the maximal density that still allowed optimal growth (3 larvae/ml) (Additional file 19 A-C). Under these conditions, juvenile Platynereis begin to develop the $5^{\text {th }}$ segment at $16 \mathrm{dpf}$, and start to undergo cephalic metamorphosis at $24 \mathrm{dpf}$. Morpholino knockdown methods are not applicable to such late stage animals, therefore we tested the effects of MIP treatment on errant juvenile growth. We found that the time to the addition of new posterior segments, and to cephalic metamorphosis, was reduced by sustained exposure to five different versions of mature MIP encoded by the Platynereis MIP preproneuropeptide gene (Figure 5E, F). At $25 \mathrm{dpf}$, some MIP-treated individuals had completed cephalic metamorphosis, while control individuals were yet to undergo cephalic metamorphosis. Comparing the body length of MIP-treated and control Platynereis at $25 \mathrm{dpf}$ revealed that MIP-treated individuals were on average approximately $100 \mu \mathrm{M}$ longer than control individuals (Figure 5G). The effect of MIP treatment on growth was only seen in the presence of food. In the absence of food, MIP treatment could not induce the addition of any new posterior segments, and postlarvae remained at the 3-segmented stage (Additional file 19E). Additionally, MIP-treated larvae, both fed and unfed, exhibited altered pigmentation of the gut and the body (Figure $5 \mathrm{H}$, Additional file 19F, G).

\section{Discussion}

Our results established the MIP neuropeptide as a regulator of postlarval feeding and gut activity in Platynereis. At $6 \mathrm{dpf}$, MIP is expressed in both the pharynx and the hindgut in neurons with a sensory morphology with dendrites projecting to the lumen. The MIP-expressing neurons of the Platynereis gut possess several hallmark features of mammalian enteroendocrine cells, including a scattered distribution, dendrites extending towards the gut lumen and long branching axons in the gut epithelial layer underlying the gut musculature [56]. These results are consistent with a model where MIP cells receive sensory signals from inside the mouth and the gut and respond by releasing MIP in a neurosecretory manner in the vicinity of the pharynx and hindgut muscles. However, given the use of bath-application and whole-body morpholino knock-down, we could not analyze the function of individual MIP-expressing cells. In principle, MIP-expressing neurons in other parts of the body may also affect gut activity by hormonal action.

Contrary to its name, MIP plays a myostimulatory role in the Platynereis digestive system. This may be the result of a direct effect whereby MIP directly acts on the digestive system musculature to increase the rate of pharynx extensions and peristaltic movements. Alternatively, the myostimulatory action of MIP may be caused indirectly through the regulation by MIP of other neurons in the gut, for example, in an as yet unidentified central pattern generator circuit responsible for regular gut contractions, as seen in crustaceans [57]. Knowledge of the spatial expression pattern of the MIP receptor in $6 \mathrm{dpf}$ and older Platynereis larvae could help to resolve this.

Our results show that the increase in pharynx extensions in Platynereis postlarvae has a direct effect on the amount of food ingested. Increased gut peristalsis could promote the passage of food within the gut or the mixing of food with digestive enzymes, speeding up digestion. The fact that the highest concentration of MIP treatment, $50 \mu \mathrm{M}$, did not increase the amount of food ingested compared to control postlarvae is likely a result of the simultaneous reduction in locomotor activity caused by MIP treatment. At the highest concentrations of MIP (20 - 50 


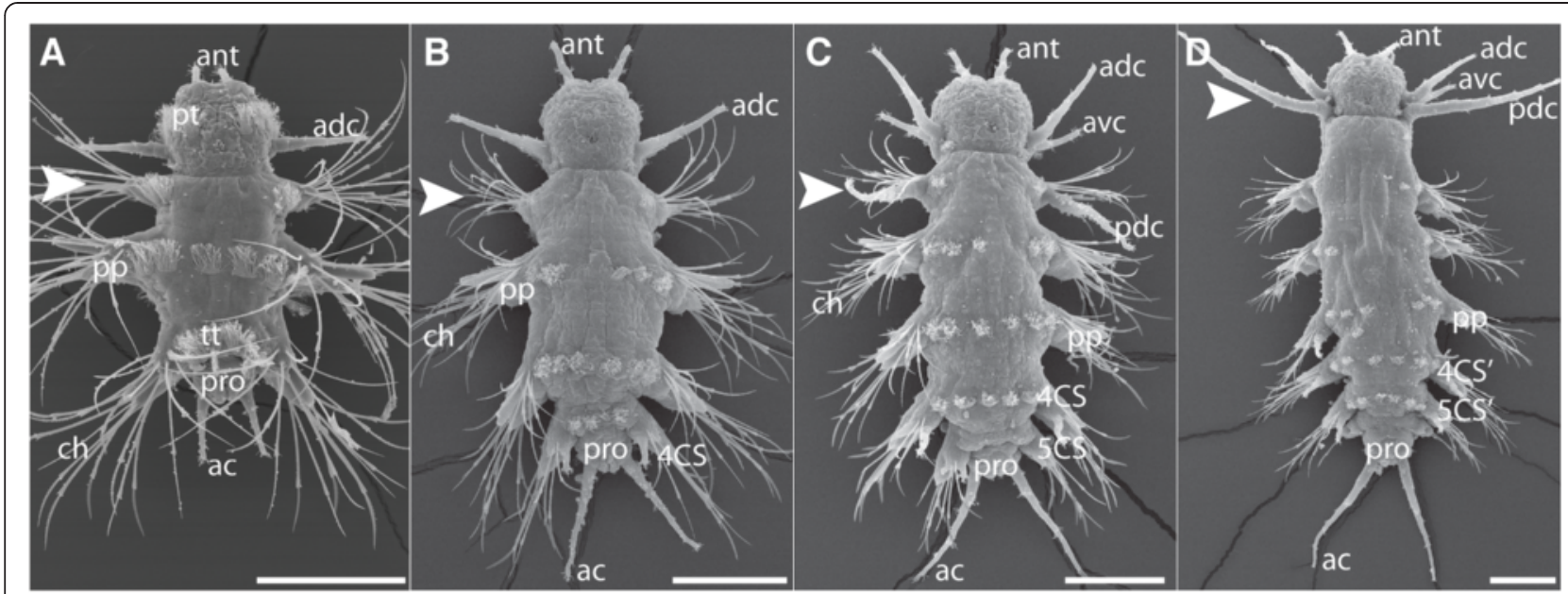

E Platynereis MIP precursor

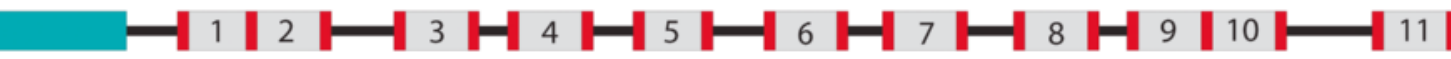

AWMKNNIAWa (MIP1); GWKQGASYSWa (MIP2); AWNKNNMRVWa (MIP3); GWKDSSMRVWa (MIP4); WGKNNLRVWa (MIP5); AWGDNNMRVWa (MIP6); AWNKNSMRVWa (MIP7); AWKGQSARVWa (MIP8), GWNGNSMRVWa (MIP9); GWHGNGVRQWa (MIP10); AWAKNNMRVWa (MIP11).
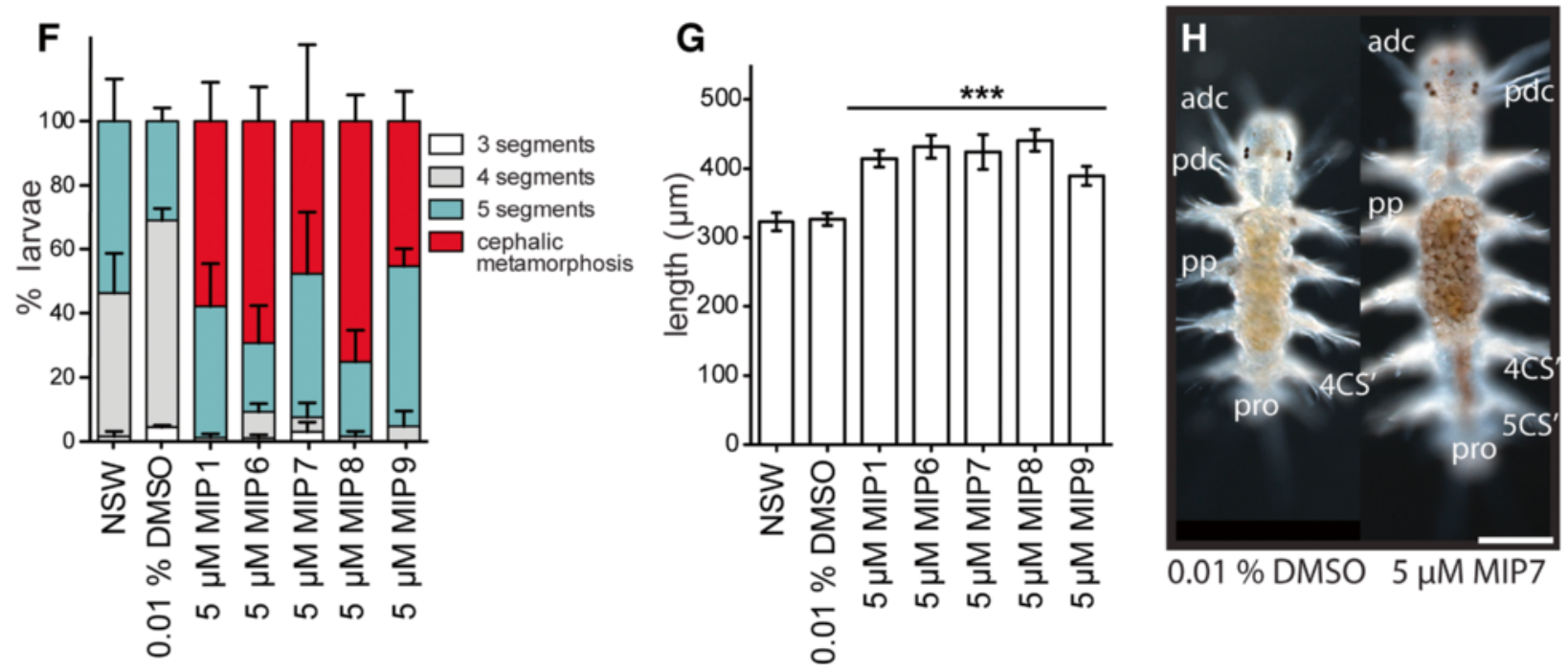

Figure 5 Long-term treatment of Platynereis with synthetic MIP enhances growth and decreases time to cephalic metamorphosis. (A-D) SEM images depicting posterior segment addition followed by cephalic metamorphosis in Platynereis dumerilii, dorsal views. White arrowhead indicates parapodia of the $1^{\text {st }}$ chaetigerous segment, which are transformed into the posterior tentacular cirri of the head during cephalic metamorphosis. (A) 6 dpf 3-segmented nectochaete larva. (B) 4-segmented errant juvenile. (C) 5-segmented errant juvenile. Cephalic metamorphosis has begun. (D) Cephalic metamorphosis is complete. (E) Schematic of the Platynereis MIP precursor protein. The N-terminal signal peptide (teal) and the predicted peptides (grey) flanked by basic cleavage sites (red) are shown. The predicted mature MIP peptide sequences are indicated below. (F) Percentage of 25 dpf Platynereis larvae/juveniles with 3, 4, 5 segments, or complete cephalic metamorphosis following exposure to $5 \mu \mathrm{M}$ synthetic MIP peptides, from $4 \mathrm{dpf}$ onwards. Data are shown as mean $+/-$ s.e. $\mathrm{m}, \mathrm{n}=3 \times 30$ larvae. NSW, natural seawater control. (G) Total length of $25 \mathrm{dpf}$ Platynereis larvae/juveniles exposed to $5 \mu \mathrm{M}$ synthetic MIP peptides, from $4 \mathrm{dpf}$ onwards. Data are shown as mean $+/-95 \%$ confidence interval, $n=90$ larvae. $(\mathbf{F}, \mathbf{G}) \mathrm{p}$-value cut-offs based on unpaired $t$-test: ${ }^{* * *}<0.001 ;{ }^{* *}<0.01 ;{ }^{*}<0.05$. (H) Differential interference contrast light micrographs of example control and MIP7-treated individuals at 1 month post fertilization. Scale bars: 100 $\mu \mathrm{M}$. Abbreviations: ac, anal cirrus; adc, anterior dorsal cirrus; ant, antenna; avc, anterior ventral cirrus; ch, chaetae; pdc, posterior dorsal cirrus; pp, parapodia; pro, proctodeum; pt, prototroch; tt, telotroch; $4 \mathrm{CS}, 4^{\text {th }}$ chaetigerous segment; $5 \mathrm{CS}, 5^{\text {th }}$ chaetigerous segment; $4 \mathrm{CS}^{\prime}, 4^{\text {th }}$ chaetigerous segment after cephalic metamorphosis; $5 \mathrm{CS}^{\prime}, 5^{\text {th }}$ chaetigerous segment after cephalic metamorphosis. 
$\mu \mathrm{M})$, increased gut peristalsis and pharynx extension activity may be offset by a decrease in locomotion, resulting in treated individuals encountering fewer algal cells.

The sustained expression of MIP in the gut and the long-term effects of MIP on juvenile growth indicate that MIP also has an important physiological role later in the life cycle. We interpret the enhancement of juvenile growth in long-term MIP treatment experiments to be a consequence of a sustained increase in feeding caused by MIP. Given its effect on both settlement and growth, MIP treatment may be a useful means of enhancing both larval settlement and juvenile growth in polychaete aquaculture [58].

Interestingly, MIP has a myostimulatory role in cnidarians and in the Platynereis digestive system, but a myoinhibitory role in the arthropod digestive system $[36,41,44]$. This could mean that either MIP was independently recruited to regulate gut activity in different phyletic lineages, or that the sign of the regulation switched during evolution. In the latter case, MIP would represent a conserved bilaterian gut peptide influencing feeding. Further comparative morphological and molecular studies of MIP cells and signaling pathways in a broader range of taxa will be needed to resolve this.

MIP regulates both settlement behavior and feeding, two aspects of the pelagic-to-benthic transition of the non-feeding Platynereis larvae. What could be the reason for the redeployment of the same peptidergic signal at different times during development and in different contexts? One possibility is that the anterior MIPexpressing sensory-neurosceretory cells of the larva and the MIP cells in the gut of the postlarva sense the same chemical cues released by potential food sources. Some marine larvae are induced to settle by their future juvenile food source [2]. Testing this hypothesis will require the identification of naturally occurring settlement cues and their corresponding receptors in Platynereis.

In Platynereis, juvenile feeding is an essential requirement for the completion of cephalic metamorphosis. In other polychaete species, where feeding often begins in the pelagic larval stage before settlement, feeding is also an essential component for settlement and metamorphosis. Starved larvae of Capitella sp., Polydora ligia, Hydroides elegans and Phragmatopoma lapidosa all lose or have decreased ability to complete settlement and metamorphosis [59-62]. Exploration of the roles of MIP in polychaete species with feeding larvae would increase our understanding of the links between MIP signaling, larval settlement and feeding.

\section{Conclusions}

We have described a role for MIP in Platynereis postlarval feeding and established methods for studying the neuroendocrine regulation of feeding, providing the basis for future studies in this area. The amenability of Platynereis larvae to peptide treatments by soaking, their transparent body wall, and a neuropeptide complement that overlaps with that of both vertebrates and arthropods, make Platynereis an ideal model with which to study the neuroendocrine regulation of feeding in an evolutionary context.

\section{Methods}

\section{Platynereis culture}

Platynereis larvae were obtained from an in-house culture as previously described [15]. After fertilization of eggs, developing embryos and larvae were kept in an incubator at a constant temperature of $18^{\circ} \mathrm{C}$ with a regular light-dark cycle.

\section{Platynereis digestive system marker genes}

Five genes with spatial expression domains restricted to the digestive system were identified from an ongoing RNA in situ hybridization screen of $48 \mathrm{hpf}, 72 \mathrm{hpf}$ and $6 \mathrm{dpf}$ Platynereis. These genes were identified as subtilisin-1 and subtilisin-2 (Genbank Accession KM577672, KM577673), alpha amylase (Genbank Accession KM577675), legumain-protease-precursor (Genbank Accession KM77676) and enteropeptidase (Genbank Accession KM577674).

Genes were named according to their common conserved domains, reciprocal BLAST to the Homo sapiens peptidome, and neighbor-joining and maximum likelihood phylogenetic analyses (Additional files 7, 8). Genes were analyzed for the presence of a signal peptide assigned using the SignalP 4.1 server (http://www.cbs.dtu.dk/services/ SignalP/) and conserved domains assigned by searches in the Pfam database with an e-value cutoff 1e-06 (http:// pfam.xfam.org/search). To find additional sequences for use in phylogenetic analyses, the candidate gene sequences were used as queries in BLAST searches against the NCBI $\mathrm{nr}$ and Swissprot databases, taking the top 50 hits from each BLAST search. To diversify the range of phyla represented, BLAST searches were also performed with different restrictions, including 'non-mammal', 'non-Drosophila' and 'Lophotrochozoans'. Sequence redundancy was reduced to $90 \%$ identity using CD-HIT [63]. Genes were aligned to candidate orthologues from other taxa with MUSCLE (http://www.ebi.ac.uk/Tools/msa/muscle/). Conserved regions of sequence alignment were select for phylogenetic analysis using Gblocks with minimal stringency settings [64]. Phylogenetic trees were constructed from trimmed sequence alignments using the neighbor-joining methods with 1000 bootstrap replicates in CLC Genomics Workbench 5.5.1 (CLC Bio, Qiagen), with a Gap Open Cost of 10 and a Gap Extension Cost of 1. Maximum likelihood trees with 100 bootstrap replicates were constructed using PhyML 3.0 using an LG substitution model and SPR and NNI tree searching methods [65]. Trees were inspected and taxa with long branches were removed to avoid long- 
branch attraction bias. The phylogenetic analyses were then re-run with the remaining taxa. We then went on to examine the expression of the digestive system marker genes in $6 \mathrm{dpf}, 15 \mathrm{dpf}$ and $1 \mathrm{mpf}$ Platynereis by RNA in situ hybridization methods as described below.

\section{RNA In situ hybridization}

Different developmental stages of Platynereis were collected for fixation for use in wholemount RNA in situ hybridization and immunostaining techniques. Individuals 6 days and older were relaxed using $1 \mathrm{M} \mathrm{MgCl}_{2}$ [66] prior to fixation. Postlarvae and juveniles that had begun feeding were starved for a few days prior to fixation to avoid the presence of autofluorescent algae cells in the gut, which interfere with fluorescent signals from immunostaining. All animals were fixed in $4 \%$ paraformaldehyde (PFA) in 0.1 M MOPS (pH 7.5), $2 \mathrm{mM} \mathrm{MgSO}{ }_{4}, 1$ mM EGTA, $0.5 \mathrm{M} \mathrm{NaCl}$ for $1 \mathrm{~h}$ at room temperature. Fixed larvae were dehydrated through a $\mathrm{MeOH}$ series and stored in $100 \% \mathrm{MeOH}$ at $-20^{\circ} \mathrm{C}$.

DIG-labelled antisense RNA probes for the Platynereis MIP precursor (JX513877), MIP receptor (JX513876), alpha-amylase, subtilisin-1, subtilisin-2, legumain-protease precursor, and enteropeptidase were synthesized from purified PCR products of clones sourced from a Platynereis cDNA library [51]. RNA in situ hybridization using nitroblue tetrazolium (NBT)/5-bromo-4-chloro-3-indolyl phosphate (BCIP) staining combined with mouse antiacetylated-tubulin staining to highlight cilia and nervous system, followed by imaging with a Zeiss LSM 780 NLO confocal system and Zeiss ZEN2011 Grey software on an AxioObserver inverted microscope, was performed as previously described [50], with the following modification: fluorescence (instead of reflection) from the RNA in situ hybridization signal was detected using excitation at 633 $\mathrm{nm}$ in combination with a Long Pass 757 filter. Animals were imaged with a 40X oil objective.

\section{Image registration of RNA in situ hybridization patterns}

We projected average MIP expression pattern of four 6 dpf individuals onto a common $6 \mathrm{dpf}$ whole-body nuclear reference template generated from DAPI signal of 40 individuals as described previously for $72 \mathrm{hpf}$ larvae [50]. Acetylated tubulin and expression patterns of digestive system marker genes of select individuals were also projected onto the reference template. Snapshots and video of the projected genes were generated in Blender 2.7.1 (http://www.blender.org/).

\section{Immunostaining}

Immunohistochemistry with $1 \mu \mathrm{g} / \mathrm{ml}$ rabbit anti-MIP (AWNKNSMRVWamide) or cross-species anti-VWa, 0.5 $\mu \mathrm{g} / \mathrm{ml}$ mouse anti-acetylated tubulin (Sigma) primary antibodies, and $1 \mu \mathrm{g} / \mathrm{ml}$ anti-rabbit Alexa Fluor ${ }^{\odot} 647$
(Invitrogen) and $0.5 \mu \mathrm{g} / \mathrm{ml}$ anti-mouse FITC (Jackson Immuno Research) secondary antibodies, was performed as previously described [67]. After the staining procedure, samples were mounted in 97\% 2,2'-thiodiethanol (TDE).

For phalloidin stainings, we used freshly-PFA-fixed larvae dehydrated in $100 \%$ acetone for 5 minutes. Staining with rhodamine phalloidin (Molecular Probes) 1:100 in combination with the rabbit anti-MIP antibody was performed with the standard protocol adapted from [67]. After the staining procedure, samples were transferred to the mounting medium $87 \%$ glycerol containing $2.5 \mathrm{mg} /$ $\mathrm{mL}$ of anti-photobleaching reagent DABCO (Sigma, St. Louis, MO, USA), as phalloidin-conjugated rhodamine destabilizes in TDE [68].

Confocal images were processed with Imaris 6.4 (Bitplane Inc., Saint Paul, USA) software. Raw image stacks and the Platynereis $6 \mathrm{dpf}$ nuclear stained reference are available at the Dryad data repository.

\section{Calcium imaging}

Fertilized eggs were injected with $500 \mathrm{ng} / \mu \mathrm{l}$ capped and polyA-tailed GCaMP6 [69] RNA generated from a vector (pUC57-T7-RPP2-GCaMP6) containing the GCaMP6 ORF fused to a 169 base pair 5' UTR from the Platynereis $60 \mathrm{~S}$ acidic ribosomal protein P2, as in [70]. Injection protocol is described in more detail in the 'Morpholino Knockdown of Platynereis MIP' section. Larvae were imaged with a $488 \mathrm{~nm}$ laser and transmission imaging with DIC optics on a Zeiss LSM 780 NLO confocal system on an AxioObserver inverted microscope (Additional file 5), or using a Zeiss AxioZoom V16 microscope with Hamamatsu OrcaFlash 4.0 digital camera (Additional file 13).

\section{RNA-Seq}

RNA-Seq analysis of digestive enzyme and MIP precursor gene expression was performed on an existing dataset of 13 different stages spanning the Platynereis life cycle, from egg to mature adults. Methods used were described in [51].

\section{Documentation of normal feeding in Platynereis}

To document variation in the commencement of feeding in Platynereis larvae from our laboratory culture, larvae were kept in Nunclon 6-well tissue culture dishes, with $10 \mathrm{ml}$ sterile filtered seawater (FSW) per well. Each well contained 30 larvae. Larvae from 6 different batches, with different parents, were used in our analysis. Larvae were fed $5 \mu \mathrm{l}$ Tetraselmis marina algae culture at $5 \mathrm{dpf}$. Larvae were then tested for feeding by checking for the presence of fluoresent Tetraselmis algae in the gut using a Zeiss Axioimager Z1 microscope with an AF488 fluorescent filter and a 20X objective. Larvae were checked for signs of feeding at 5.5, 6, 7, 8, 10, 12 and $14 \mathrm{dpf}$. After ingestion, algal cells can remain in the gut for up 
to $48 \mathrm{~h}$ before digestion causes a loss of fluorescence. Although larvae with a full gut can also be identified with normal light microscopy due to the transparent body wall, fluorescent microscopy enables the detection of even a single alga cell in the gut, due to the strong chlorophyll fluorescence of the Tetraselmis cells.

\section{Morpholino knockdown of Platynereis MIP}

Two translation blocking morpholinos (MOs) and two corresponding 5 base pair mismatch control morpholinos were designed to target the Platynereis-MIP-precursor (GeneTools, LLC):

Pdu-MIP-start MO1 TGATAGTGACGCGATCCATTG GACT

Pdu-MIP-mism MO1 TGTTAGTGACCCGTTCGAATG GACT

Pdu-MIP-start MO2 CTAGTTCCTTCTCTCCCTCTT ATCT

Pdu-MIP-mism MO2 CTACTTGCTTGTCTCCGTGT TATCT

Nucleotides altered in mismatch control morpholinos are in italics. Information on the position of the morpholinos in relation to the MIP start codon can be found in Additional file 11.

MOs were diluted in water with $12 \mu \mathrm{g} / \mu \mathrm{l}$ fluorescein dextran $(M r$ 10,000, Invitrogen) as a fluorescent tracer. $0.6 \mathrm{mM}$ MOs were injected with an injection pressure of $600 \mathrm{hPa}$ for $0.1 \mathrm{~s}$ and a compensation pressure of $35 \mathrm{hPa}$ using Eppendorf Femtotip II needles with a Femtojet microinjector (Eppendorf) on a Zeiss Axiovert $40 \mathrm{CL}$ inverted microscope equipped with a Luigs and Neumann micromanipulator. The temperature of developing zygotes was maintained at $16^{\circ} \mathrm{C}$ throughout injection using a Luigs and Neumann Badcontroller V cooling system and a Roth Cyclo 2 water pump.

For microinjection, fertilized Platynereis eggs developing at $16^{\circ} \mathrm{C}$ were rinsed $1 \mathrm{~h}$ after fertilization with sterile $0.2 \mu \mathrm{m}$ filtered seawater (FSW) in a $100 \mu \mathrm{M}$ sieve to remove the egg jelly, followed by a treatment with $70 \mu \mathrm{g} / \mathrm{ml}$ proteinase $\mathrm{K}$ for $1 \mathrm{~min}$ to soften the vitellin envelope. Following injection, embryos were raised in Nunclon 6-well plates in 10 $\mathrm{ml} \mathrm{FSW}$ and their development was monitored daily.

Larvae were fed $5 \mu \mathrm{l}$ Tetraselmis marina algal culture at $6 \mathrm{dpf}$. Feeding in $7-14 \mathrm{dpf}$ injected larvae was assessed by checking for the presence of fluoresent Tetraselmis marina algae in the gut using a Zeiss Axioimager $\mathrm{Z} 1$ microscope with an AF488 fluorescent filter and a 20X objective. Larvae were checked for signs of feeding as described above every $24 \mathrm{~h}$ from $7 \mathrm{dpf}$ on. We scored a minimum of 62 larvae (maximum 424 larvae) from a minimum of 3 separate microinjection sessions (with 3 different batches of larvae) for each translation-blocking and control morpholino. Photomicrographs of morpholino-injected larvae were also taken and larval body length was measured from these pictures using Image J 64 software. Some morpholino-injected larvae were also fixed at 6 days for immunostaining with the anti-MIP antibody (as described above) in order to assess morpholino specificity and effectiveness.

\section{Effect of synthetic MIP on Platynereis feeding behaviour}

Peptide functions can be investigated in Platynereis larvae by bath application of synthetic neuropeptides $[10,11]$. To test whether synthetic MIP treatment increased developmental speed, leading to early initiation of feeding in Platynereis larvae, experiments were performed in Nunclon 6-well plates, with $10 \mathrm{ml} \mathrm{FSW}$ per well. Each control and peptide treatment was replicated across three wells, with 30 larvae per well. Larvae were treated with $5 \mu \mathrm{M}$ MIP7 or controls at $24 \mathrm{hpf}, 60 \mathrm{hpf}, 4 \mathrm{dpf}$ or $5 \mathrm{dpf}$, then fed at 4 or $5 \mathrm{dpf}$ (depending on the age at which MIP treatment occurred) with $5 \mu \mathrm{l}$ Tetraselmis marina algal culture. Larvae were fed at an earlier age due to the possibility of MIP treatment causing an earlier initiation of feeding. Larvae were checked for feeding by monitoring algal cell fluorescence in the gut as described above. Larvae were monitored from 5 or $5.5 \mathrm{dpf}$ (depending on age at which larvae were first fed) until 7 or $8 \mathrm{dpf}$. A control non-functional MIP peptide (MIPW2A, AANKNSMRVAamide), in which the two conserved tryptophan sites were replaced with alanines (this prevents MIP from activating its receptor, see [11]) was also tested. A further control of larvae treated with DMSO alone was also included, as MIP peptides require DMSO to be dissolved in solution.

To test the effects of synthetic MIP peptide treatment on the digestive system of Platynereis larvae, we recorded videos of groups of 60 larvae at $6.5 \mathrm{dpf}$ in a square glass cuvette $1.5 \mathrm{~cm} \times 1.5 \mathrm{~cm} \times 0.3 \mathrm{~cm}$ in $500 \mu \mathrm{l}$ of FSW using a Zeiss AxioZoom .V16 microscope with Hamamatsu OrcaFlash 4.0 digital camera. For each treatment and control, 3 biological replicates (larval batches with different parentage, fertilized on different days) were carried out. We tested three concentrations of synthetic MIP: 5, 20 and 50 $\mu \mathrm{M}$, plus $50 \mu \mathrm{M}$ control non-functional MIP peptide MIPW2A and a $0.1 \%$ DMSO control. A 2.5 min video at 10 frames per second was recorded $10 \mathrm{~min}$ after peptide or DMSO addition. Videos were analyzed manually in Fiji (Image J 1.48s, Wayne Rasband, http://imagej.nih.gov/ij). For each video, 20 larvae that remained within the frame of the video for the entire $2.5 \mathrm{~min}$ were scored for gut peristalsis and pharynx extension activity. Distance traveled and speed of the larvae was also measured using the MTrack2 plugin [71]. Significant differences in gut peristalsis, pharynx extension activity and locomotion in MIP-treated versus control larvae were tested in an unpaired $t$ test. 
To test the effects of synthetic MIP treatment on short-term ingestion of algal cells in Platynereis larvae, experiments were performed in Nunclon 24-well plates, with $2 \mathrm{ml} \mathrm{FSW}$ per well. Each control and peptide treatment was replicated across three wells, with 20 larvae per well. $7 \mathrm{dpf}$ postlarvae were treated with $5 \mu \mathrm{M}$ MIPW2A control peptide, $5 \mu \mathrm{M}$ MIP, $20 \mu \mathrm{M}$ MIP or $50 \mu \mathrm{M}$ MIP for $10 \mathrm{~min}$. Following this, $20 \mu \mathrm{l}$ Tetraselmis marina algal culture was added to each well and larvae were left to feed for $30 \mathrm{~min}$. All larvae were then immediately fixed in 0.5 $\mathrm{mL} 4 \%$ paraformaldehyde in $1 \mathrm{X}$ PBS with $0.01 \%$ Tween (PTw) for 1 hour. Following 4 washes in $1 \mathrm{ml} \mathrm{PTw}$, larvae were mounted on glass slides and the number of algal cells in the digestive system of each larva was counted using a Zeiss Axioimager Z1 microscope with an AF488 fluorescent filter and a 20X objective. Significant differences in MIP-treated versus control larvae were tested in an unpaired $t$ test.

\section{Scanning electron microscopy (SEM)}

Platynereis larvae and juveniles of different developmental stages were fixed with $3 \%$ glutaraldehyde in $0.1 \mathrm{M}$ phosphate buffer $\mathrm{pH} 7.2$, rinsed in phosphate buffer, further fixed with $1 \%$ osmium tetroxide in water and dehydrated in an ascending $\mathrm{EtOH}$ series over several days. Critical point drying with carbon dioxide was performed in a Polaron E 3000. The samples were coated with goldpalladium in a Balzers MED 010. Images were taken on a Hitachi S-800 Scanning electron microscope.

\section{Calculation of optimal culture density}

The assessment of growth in larvae cultured individually was performed in a Nunclon 24-well tissue culture dish with 1 larva per well in $2 \mathrm{ml}$ FSW. Larvae were fed from $6 \mathrm{dpf}$ with $3 \mu \mathrm{l}$ Tetraselmis marina algae culture. Larvae were scored under a dissection microscope for number of segments and cephalic metamorphosis every $48 \mathrm{~h}$ from 14 dpf to $34 \mathrm{dpf}$.

Documentation of growth in larvae cultured at different densities was carried out in Nunclon 6-well plates with $10 \mathrm{~mL} \mathrm{FSW/well} \mathrm{and} \mathrm{30,} 50$ or 100 larvae per well. Three replicate wells were included for each culture density. Larvae were fed with surplus Tetraselmis marina algae throughout the experiment. Larvae were scored for segment number and cephalic metamorphosis every 4 days from 16 to $32 \mathrm{dpf}$.

\section{Long term treatment of Platynereis with synthetic MIP}

To test the effect of synthetic MIP treatment on growth in Platynereis larvae, we again carried out experiments in Nunclon 6-well plates as described above, with 30 larvae per well and 3 replicate wells per treatment and control. $5 \mu \mathrm{M}$ synthetic peptides were added at $4 \mathrm{dpf}$. Different versions of mature MIP peptide tested were:
MIP1 - AWNKNNIAWamide, MIP6 - AWGDNNMRV Wamide, MIP7 - AWNKNSMRVWamide, MIP8 - AW KGQSARVWamide, and MIP9 - GWNGNSMRVWamide. Larvae were also fed at $4 \mathrm{dpf}$ with $5 \mu \mathrm{l}$ Tetraselmis $s p$. algal culture. At $25 \mathrm{dpf}$ (21 days after peptide addition), errant juveniles were scored for number of segments and cephalic metamorphosis (as above). Juveniles were also photodocumented using a Zeiss Axioimager Z1 microscope with differential interference contrast (DIC) and size of control and treated larvae (end of head to end of pygidium, excluding cirri) was measured in Fiji (Image J 1.48s, Wayne Rasband, http:// imagej.nih.gov/ij).

We also tested the effects of synthetic MIP treatment on growth of unfed Platynereis larvae. Experiments were carried out as above, $5 \mu \mathrm{M}$ MIP7 was added at $4 \mathrm{dpf} .5$ $\mu \mathrm{M}$ MIPW2A and $0.1 \%$ DMSO were included as negative controls. At $24 \mathrm{dpf}$, errant juveniles were scored for number of segments and cephalic metamorphosis. Most unfed juveniles died between 24 and $28 \mathrm{dpf}$.

\section{Additional files}

\begin{abstract}
Additional file 1: MIP expression in $14 \mathrm{dpf}$ and $1 \mathrm{mpf}$ Platynereis. Whole-mount RNA in situ hybridization (WMISH) for the Platynereis MIP precursor (red) counterstained for acetylated tubulin (white) (A, C, D, E, G, $H)$, or DAPI nuclear stain (blue) $(B, F)$. All images shown in ventral view, with head to top. (A-D) $14 \mathrm{dpf},(E-H) 1 \mathrm{mpf}$. In (B-D) and (F-H), the ventral nerve cord region has been cut away to reveal digestive system. $(C, G)$ close-up foregut $(D, H)$ close-up mid- and hindgut. (I-K) Schematic of MIP precursor expression in $1 \mathrm{mpf}$ Platynereis. (I) Ventral side. (J) Dorsal side. (K) MIP expression relative to expression of digestive system marker genes. In (B) and (F), white dashed lines indicate digestive system. In (B), $(C),(F)$ and $(G)$, yellow dashed lines mark jaws. Scale bars: $50 \mu \mathrm{m}$. Abbreviations: fg, foregut; mg, midgut; hg, hindgut; ant, antenna; nsp, neurosecretory plexus; adc, anterior dorsal cirrus; pp, parapodia; vnc, ventral nerve cord; ch, chaetae; ac, anal cirrus; ph, pharynx.
\end{abstract}

Additional file 2: Movie of MIP expression in foregut sensory cell of 6 dpf Platynereis. Whole-mount RNA in situ hybridization (WMISH) for the Platynereis MIP precursor (red) counterstained for acetylated tubulin (white) and DAPI nuclear stain (blue). Ventral view of foregut. Yellow arrowhead marks sensory dendrite of MIP-expressing cell. Green arrows indicate salivary glands.

Additional file 3: Movie of MIP expression in mid- and hindgut sensory cells of 6 dpf Platynereis. Whole-mount RNA in situ hybridization (WMISH) for the Platynereis MIP precursor (red) counterstained for acetylated tubulin (white) and DAPI nuclear stain (blue). Ventral view of mid- and hindgut. Yellow arrowheads mark sensory dendrites of MIP-expressing cells.

Additional file 4: MIP peptide expression timecourse in Platynereis, MIP peptide expression in Capitella larvae. (A-L) Immunostaining of Platynereis larvae, postlarvae and juveniles with an antibody raised against Platynereis MIP7 (red), counterstained for acetylated tubulin (white) or DAPI nuclear stain (blue). All images ventral view with head to top. (A, B) $3 \mathrm{dpf},(\mathrm{C}, \mathrm{D}) 4 \mathrm{dpf},(\mathrm{E}, \mathrm{F}) 5 \mathrm{dpf},(\mathrm{G}, \mathrm{H}) 6 \mathrm{dpf}$, (I, J) $10 \mathrm{dpf}$, (K, L) $1 \mathrm{mpf}$. (M-P) Immunostaining of Capitella teleta Stage 9 larvae with an antibody raised against Wamide (red), counterstained for acetylated tubulin (white) or DAPI nuclear stain (blue). $(M, N)$ ventral view, $(O, P)$ lateral view. In $(B, D$, $F, H, J, L, N$ ), ventral nerve cord area has been removed to expose the underlying digestive system. Scale bars: $50 \mu \mathrm{m}$. White asterisks mark background fluorescence of parapodia, chaetae or spinning glands. White dashed lines indicate the developing digestive system. Abbreviations: fg, 
foregut; mg, midgut; hg, hindgut; pro, proctodeum; sto, stomodeum; dpf, days post fertilization; mpf, month post fertilization.

\section{Additional file 5: Video of Platynereis $6 \mathrm{dpf}$ digestive system.} Calcium imaging with GCaMP6 shows muscular and neuronal activity in the digestive system of $6 \mathrm{dpf}$ Platynereis. A sphincter muscle (indicated by yellow arrowheads) marks the boundary between foregut and midgut. Dorsal view with head to right.

\section{Additional file 6: Platynereis digestive system marker genes.}

Schematic representation of Platynereis digestive enzyme genes alpha-amylase, enteropeptidase, legumain protease precursor, subtilisin-1 and subtilisin-2. Signal peptide sequence and conserved domains are marked by coloured boxes, with e-value of an HMM search against the Pfam database (http://pfam.xfam.org) indicated in box. Length of amino acid sequence obtained is shown to the right of each gene.

Additional file 7: Phylogenetic trees of Platynereis digestive system marker genes. Neighbour-joining trees with 1000 bootstrap repetitions (NJ-1000) and maximum likelihood trees with 100 bootstrap repetitions (ML-100) for digestive system markers alpha amylase (A, B), enteropeptidase $(\mathrm{B}, \mathrm{C})$, legumain protease precursor $(\mathrm{D}, \mathrm{E})$, and subtilisin-1 and subtilisin-2 $(\mathrm{F}, \mathrm{G})$. The positions of the Platynereis candidate genes are highlighted by green boxes. Bootstrap values are indicated at branch nodes. Platynereis alpha amylase and legumain protease precursor cluster with their counterparts in a fellow polychaete, Capitella teleta, within invertebrate-specific clades. The orthology of these genes was confirmed by reciprocal BLAST to the Homo sapiens peptidome. Platynereis enteropeptidase clusters in a weakly-supported group of annelid enteropeptidases, however the identity of this gene is confirmed by the presence of conserved MAM and trypsin domains (Additional file 6) [49]. Platynereis subtilisin-1 and subtilisin-2 are intermingled with several bacterial, fungal, annelid and echinoderm sequences in a poorly resolved tree, suggesting a possible horizontal gene transfer event. Subtilisin-1 and -2 contain conserved peptidase domains (Additional file 6), including the presence of a catalytic triad, suggesting that they maintain enzymatic function in Platynereis.

Additional file 8: Expression timecourse of Platynereis digestive system marker genes. Whole-mount RNA in situ hybridization (WMISH) for Platynereis digestive system marker genes (red) counterstained for DAPI nuclear stain (blue). Ventral view with the head to the top, ventral nerve cord region removed to show the digestive system. (A-C) alpha amylase, (D-F) enteropeptidase, (G-I) legumain protease precursor, (J-L) subtilisin-2, (M-O) subtilisin-2. (A, D, $\mathrm{G}, \mathrm{J}, \mathrm{M}) 6 \mathrm{dpf},(\mathrm{B}, \mathrm{E}, \mathrm{H}, \mathrm{K}, \mathrm{N}) 14 \mathrm{dpf},(\mathrm{C}, \mathrm{F}, \mathrm{I}, \mathrm{L}, \mathrm{O}) 1 \mathrm{mpf}$. White asterisks mark background fluorescence from jaws or chaetae. White dashed lines indicate the digestive system. Abbreviations: fg, foregut; mg, midgut; hg, hindgut. Scale bars: $50 \mu \mathrm{m}$.

\section{Additional file 9: Movie of average MIP expression in $6 \mathrm{dpf}$} Platynereis in relation to digestive system marker genes. Surface representation of the average expression domains of MIP (blue) at $6 \mathrm{dpf}$ relative to the axonal scaffold (grey). Surface representations of digestive enzyme genes are added sequentially to mark the digestive system. In order of appearance, genes are: alpha amylase (orange), enteropeptidase (cyan), subtilisin-2 (green), legumain protease precursor (purple), and subtilisin-1 (pink). Movie starts in dorsal view with head to the top and rotates around anterior-posterior axis.

Additional file 10: Expression of MIP and digestive system marker genes throughout Platynereis life cycle. Histograms of normalized gene expression generated from RNA-Seq libraries of 13 different life-cycle stages, from egg to sexually mature epitokes. (A) alpha amylase (B) enteropeptidase, (C) legumain protease precursor, (D) subtilisin-1 (E) subtilisin-2 and (F) MIP. Life-cycle stages during which Platynereis feeds are $10 \mathrm{dpf}, 15 \mathrm{dpf}, 1 \mathrm{mpf}$ pre-cephalic metamorphosis, $1 \mathrm{mpf}$ post-cephalic metamorphosis, and $3 \mathrm{mpf}$ atokous adult. Habitat transitions are also indicated under the histograms: pelagic, free-swimming; benthic, crawling on bottom; pelagobenthic, may switch between swimming and crawling.

Additional file 11: Target sites of Platynereis MIP start morpholinos. The sequence of the $5^{\prime}$ region of the Platynereis MIP precursor gene is shown. Binding sites of MIP start morpholinos (MOs) 1 and 2 are outlined in red. The start codon for the MIP precursor peptide is underlined and in bold. The 5' predicted peptide sequence is indicated in grey. MIP start
MO1 binds to the start codon region of the gene, while MIP start MO2 binds in the upstream 5'-UTR region.

Additional file 12: MIP knockdown in Platynereis is confirmed by anti-MIP immunostaining. Immunostaining of $6 \mathrm{dpf}$ Platynereis with an antibody raised against Platynereis MIP7 (red). All images in apical view. (A-C) Larvae injected with mismatch control morpholino 1. (D-K) Larvae injected with MIP start morpholino 1. (L-N) Larvae injected with mismatch control morpholino 2. (O-Q) Larvae injected with MIP start morpholino 2. Injection of morpholinos targeting the start site of MIP results in reduced expression of MIP peptide compared to injection of control morpholinos. Black asterisks in (A-K) indicate background fluorescence caused by the oxidation of eye pigment proteins in larvae exposed to strong light. Scale bars: $20 \mu \mathrm{M}$.

Additional file 13: MIP knockdown Platynereis are morphologically similar to control Platynereis. $(A, B)$ Ventral view of $6 \mathrm{dpf}$ Platynereis injected with MIP mismatch morpholino 1 (A) or MIP start morpholino 1 (B) and immunostained with Platynereis MIP antibody (red) counterstained with acetylated tubulin (grey). Identical confocal microscopy and image processing parameters were applied to all images. Scale bar: $100 \mu \mathrm{m}$. Abbreviations: mism, mismatch; MO, morpholino; a-acTub, anti acetylated tubulin.

Additional file 14: Early treatment with MIP does not induce early onset feeding. Graphs of \% larvae with food in gut over time after treatment with $5 \mu \mathrm{M}$ MIP, $5 \mu \mathrm{M}$ control MIPW2A or $0.1 \%$ DMSO from (A) $24 \mathrm{hpf}$, (B) $60 \mathrm{hpf}$ (C) $4 \mathrm{dpf}$, or (D) $5 \mathrm{dpf}$. Data are shown as mean +/- s.e. m., $n=3 \times 30$ larvae. $p$-value cut-offs based on unpaired $t$-tests indicated no significant difference in initiation of feeding between MIP-treated and control larvae. MIPW2A is a control non-functional MIP peptide in which the two conserved tryptophan sites are substituted with alanines.

Additional file 15: Movie of gut peristalsis in $6.5 \mathrm{dpf}$ Platynereis. Dorsal view with head to the right. Extension of pharynx can also be seen at $10 \mathrm{sec}$ and $15 \mathrm{sec}$.

Additional file 16: Movie of pharynx extension in $6.5 \mathrm{dpf}$ Platynereis. Dorsal view with head to the right. Calcium imaging with GCaMP6 shows muscular extension of the pharynx in the foregut. Top panel is differential interference contrast (DIC), bottom panel is colour-coded with Jet-LUT colour map in Image J, most intense signal in red.

Additional file 17: Movie of feeding in $7 \mathrm{dpf}$ Platynereis. Platynereis (green) feeds on autofluorescent Tetraselmis algae (red). Movie was filmed on a Zeiss AxioZoom microscope with AF488 fluorescent filter.

Additional file 18: MIP treatment decreases distance traveled and speed of $6 \mathrm{dpf}$ Platynereis. (A) Distance travelled by MIP-treated versus control $6.5 \mathrm{dpf}$ Platynereis. (B) Speed of MIP-treated versus control $6.5 \mathrm{dpf}$ Platynereis. Data are shown as mean $+/-95 \%$ confidence interval, $n=60$ larvae. p-value cut-offs based on unpaired $t$-test: ${ }^{* * *}<0.001$; ${ }^{* *}<0.01$; ${ }^{*}<0.05$. MIPW2A $=$ control non-functional MIP peptide in which the two conserved tryptophan sites are substituted with alanines.

Additional file 19: Long-term growth of Platynereis. Addition of posterior segments in errant juveniles raised at a density of (A) 3 larvae/ $\mathrm{mL}$ (30 larvae in $10 \mathrm{~mL} \mathrm{NSW}$ ), $\mathrm{n}=3 \times 30$, (B) 5 larvae $/ \mathrm{mL}$ (50 larvae in $10 \mathrm{~mL} \mathrm{NSW}$ ), $\mathrm{n}=3 \times 50$, or (C) 10 larvae/mL (100 larvae in $10 \mathrm{~mL} \mathrm{NSW}$ ), $n=3 \times 100$. (A-C) Data are shown as mean + s.e.m. All larvae were fed from $6 \mathrm{dpf}$ onwards. 'Cephalic metamorphosis' encompasses all worms that have completed cephalic metamorphosis and have 5 or more chaetigerous segments. (D) Addition of posterior segments in errant juveniles raised individually. 24 larvae were raised individually in a 24-well tissue culture dish with $2 \mathrm{~mL}$ NSW per well. Note: Larva \#13 died prior to $12 \mathrm{dpf}$. (E) No addition of posterior segments in unfed $5 \mu \mathrm{M}$ MIP7-treated and control errant juveniles. Data shown are mean + s.e. $m, n=3 \times 30$ larvae. NSW, $0.22 \mu \mathrm{M}$ filtered natural seawater. MIPW2A is a control non-functional MIP peptide in which the two conserved tryptophan sites are substituted with alanines. (F, G) Differential interference contrast (DIC) light micrographs of example unfed (F) control and (G) MIP-treated individuals at $24 \mathrm{dpf}$. Scale bar: $50 \mu \mathrm{m}$.

\section{Abbreviations}

4CS: 4th chaetigerous segment; 4CS': 4th chaetigerous segment after cephalic metamorphosis; 5CS: 5th chaetigerous segment; 5CS': 5th chaetigerous segment after cephalic metamorphosis; $a$-acTub: anti 
acetylated tubulin; ac: anal cirrus; adc: anterior dorsal cirrus; ant: antenna; AST-B: allatostatin-B; avc: anterior ventral cirrus; ch: chaetae; $\mathrm{cm}$ : circular muscle fibre; DAPI: 4',6-Diamidino-2-Phenylindole, Dihydrochloride; DIC: differential interference contrast; DMSO: dimethyl sulfoxide; dpf: days post fertilization; fg: foregut; FSW: $0.2 \mu \mathrm{m}$ filtered seawater; hg: hindgut; hpf: hours post fertilization; Im: Iongitudinal muscle fibre; mg: midgut; MIP: myoinhibitory peptide; mism: mismatch; MO: morpholino; mpf: months post fertilization; nsp: neurosecretory plexus; pdc: posterior dorsal cirrus; ph: pharynx; pp: parapodia; pro: proctodeum; pt: prototroch; PTSP: prothoracicostatic peptide; PTw: 1X PBS with $0.01 \%$ Tween; SEM: scanning electron microscopy; sto: stomodeum TDE, 2,2'-thiodiethanol; tt: telotroch; vnc: ventral nerve cord.

\section{Competing interests}

A patent application for the potential use of MIP/allatostatin B in lophotrochozoan larval culture has been submitted.

\section{Authors' contributions}

EAW and GJ conceived and designed the study. EAW performed expression analysis, morpholino knockdown and behavioral/growth assays. MC performed expression analysis. EAW, MC and GJ analyzed the data. EAW drafted the manuscript. EAW, GJ and MC revised the manuscript. All authors read and approved the final manuscript.

\section{Acknowledgements}

The authors thank Dorothee Hildebrandt for her assistance in caring for our Platynereis laboratory culture, Jürgen Berger for contributions to SEM, and Günter Purshke for sharing his knowledge of polychaete digestive systems. Aurora Panzera, Christian Liebig and Csaba Verasztó provided assistance with calcium imaging and microscopy. Reza Shahidi and Albina Asadulina assisted with image and video construction in Blender. Heiko Müller provided in situ probes for digestive system marker genes. Nadine Randel provided fixed 6 dpf Platynereis larvae for SEM. The research leading to these results received funding from the European Research Council under the European Union's Seventh Framework Programme (FP7/2007-2013)/European Research Council Grant Agreement 260821.

\section{Received: 15 September 2014 Accepted: 12 December 2014 Published online: 07 January 2015}

\section{References}

1. Rieger RM. The Biphasic Life-Cycle - a Central Theme of Metazoan Evolution. Am Zool. 1994;34:484-91.

2. Pawlik JR. Chemical Ecology of the Settlement of Benthic MarineInvertebrates. Oceanography and Marine Biology. 1992;30:273-335.

3. Rodriguez SR, Ojeda FP, Inestrosa NC. Settlement of Benthic MarineInvertebrates. Mar Ecol Prog Ser. 1993;97:193-207.

4. Underwood AJ, Keough MJ. Supply side ecology: the nature and consequences of variations in recruitment of intertidal organisms. In: Bertness MD, Gaines SD, Hay MD, editors. Marine Community Ecology. Sunderland, Massachusetts: Sinauer and Associates; 2000. p. 183-200.

5. Jackson D, Leys SP, Hinman VF, Woods R, Lavin MF, Degnan BM. Ecological regulation of development: induction of marine invertebrate metamorphosis. Int J Dev Biol. 2002;46:679-86.

6. Marshall DJ, Morgan SG. Ecological and evolutionary consequences of linked life-history stages in the sea (vol 21, pg R718, 2011). Curr Biol. 2011;21:1771-1771.

7. Gilbert SF. Ecological developmental biology: environmental signals for normal animal development. Evol Dev. 2012;14:20-8.

8. Nielsen C. Life cycle evolution: was the eumetazoan ancestor a holopelagic, planktotrophic gastraea? BMC Evol Biol. 2013;13:171.

9. Tessmar-Raible K, Arendt D. Emerging systems: between vertebrates and arthropods, the Lophotrochozoa. Curr Opin Genet Dev. 2003;13:331-40.

10. Conzelmann M, Offenburger SL, Asadulina A, Keller T, Munch TA, Jekely G. Neuropeptides regulate swimming depth of Platynereis larvae. Proc Natl Acad Sci U S A. 2011;108:E1174-83.

11. Conzelmann M, Williams EA, Tunaru S, Randel N, Shahidi R, Asadulina A, et al. Conserved MIP receptor-ligand pair regulates Platynereis larval settlement. Proc Natl Acad Sci U S A. 2013;110:8224-9.

12. Zantke J, Bannister S, Rajan VB, Raible F, Tessmar-Raible K. Genetic and genomic tools for the marine annelid Platynereis dumerilii. Genetics. 2014;197:19-31.
13. Fischer $\mathrm{AH}$, Henrich $\mathrm{T}$, Arendt $\mathrm{D}$. The normal development of Platynereis dumerilii (Nereididae, Annelida). Front Zool. 2010;7:31.

14. Hempelmann F. Zur Naturgeschichte von Nereis dumerilii Aud. et Edw. Zoologica. 1911;25:1-135.

15. Hauenschild C, Fischer A. Platynereis dumerilii. Mikroscopische Anatomie, Fortplanzung, Entwicklung. Stuttgart: Gustav Fischer; 1969.

16. Fischer A, Dorresteijn A. The polychaete Platynereis dumerilii (Annelida): a laboratory animal with spiralian cleavage, lifelong segment proliferation and a mixed benthic/pelagic life cycle. Bioessays. 2004;26:314-25.

17. Jekely G. Global view of the evolution and diversity of metazoan neuropeptide signaling. Proc Natl Acad Sci U S A. 2013;110:8702-7.

18. Schoofs L, Beets I. Neuropeptides control life-phase transitions. Proc Natl Acad Sci U S A. 2013;110:7973-4.

19. Hua YJ, Tanaka Y, Nakamura K, Sakakibara M, Nagata S, Kataoka H. Identification of a prothoracicostatic peptide in the larval brain of the silkworm, Bombyx mori. J Biol Chem. 1999;274:31169-73.

20. Davis NT, Blackburn MB, Golubeva EG, Hildebrand JG. Localization of myoinhibitory peptide immunoreactivity in Manduca sexta and Bombyx mori, with indications that the peptide has a role in molting and ecdysis. J Exp Biol. 2003;206:1449-60.

21. Liu X, Tanaka Y, Song Q, Xu B, Hua Y. Bombyx mori prothoracicostatic peptide inhibits ecdysteroidogenesis in vivo. Arch Insect Biochem Physiol. 2004;56:155-61.

22. Lorenz MW, Kellner R, Hoffmann $\mathrm{KH}$. A family of neuropeptides that inhibit juvenile hormone biosynthesis in the cricket, Gryllus bimaculatus. J Biol Chem. 1995;270:21103-8.

23. Leitz T. Metamorphosin A and related compounds - A novel family of neuropeptides with morphogenic activity. Trends in Comparative Endocrinology and Neurobiology. 1998;839:105-10.

24. Iwao K, Fujisawa T, Hatta M. A cnidarian neuropeptide of the GLWamide family induces metamorphosis of reef-building corals in the genus Acropora. Coral Reefs. 2002;21:127-9.

25. Erwin PM, Szmant AM. Settlement induction of Acropora palmata planulae by a GLW-amide neuropeptide. Coral Reefs. 2010;29:929-39.

26. Audsley N, Weaver RJ. Neuropeptides associated with the regulation of feeding in insects. Gen Comp Endocrinol. 2009;162:93-104.

27. Matsuda K, Kang KS, Sakashita A, Yahashi S, Vaudry H. Behavioral effect of neuropeptides related to feeding regulation in fish. Ann N Y Acad Sci. 2011;1220:117-26.

28. Valassi E, Scacchi M, Cavagnini F. Neuroendocrine control of food intake. Nutr Metab Cardiovasc Dis. 2008;18:158-68.

29. Simo L, Koci J, Park Y. Receptors for the neuropeptides, myoinhibitory peptide and SIFamide, in control of the salivary glands of the blacklegged tick Ixodes scapularis. Insect Biochem Mol Biol. 2013:43:376-87.

30. Simo L, Zitnan D, Park Y. Two novel neuropeptides in innervation of the salivary glands of the black-legged tick, Ixodes scapularis: myoinhibitory peptide and SIFamide. J Comp Neurol. 2009;517:551-63.

31. Carlsson MA, Diesner M, Schachtner J, Nassel DR. Multiple neuropeptides in the Drosophila antennal lobe suggest complex modulatory circuits. J Comp Neurol. 2010;518:3359-80.

32. Schulze J, Neupert S, Schmidt L, Predel R, Lamkemeyer T, Homberg U, et al. Myoinhibitory peptides in the brain of the cockroach Leucophaea maderae and colocalization with pigment-dispersing factor in circadian pacemaker cells. J Comp Neurol. 2012;520:1078-97.

33. Kolodziejczyk A, Nassel DR. A novel wide-field neuron with branches in the lamina of the Drosophila visual system expresses myoinhibitory peptide and may be associated with the clock. Cell Tissue Res. 2011;343:357-69.

34. Kolodziejczyk A, Nassel DR. Myoinhibitory peptide (MIP) immunoreactivity in the visual system of the blowfly Calliphora vomitoria in relation to putative clock neurons and serotonergic neurons. Cell Tissue Res. 2011;345:125-35.

35. Moroz LL, Edwards JR, Puthanveettil SV, Kohn AB, Ha T, Heyland A, et al. Neuronal transcriptome of Aplysia: neuronal compartments and circuitry. Cell. 2006;127:1453-67.

36. Schoofs L, Holman GM, Hayes TK, Nachman RJ, De Loof A. Isolation, identification and synthesis of locustamyoinhibiting peptide (LOM-MIP), a novel biologically active neuropeptide from Locusta migratoria. Regul Pept. 1991;36:111-9.

37. Blackburn MB, Wagner RM, Kochansky JP, Harrison DJ, Thomas-Laemont $P$, Raina AK. The identification of two myoinhibitory peptides, with sequence similarities to the galanins, isolated from the ventral nerve cord of Manduca sexta. Regul Pept. 1995;57:213-9. 
38. Blackburn MB, Jaffe $H$, Kochansky J, Raina AK. Identification of four additional myoinhibitory peptides (MIPs) from the ventral nerve cord of Manduca sexta. Arch Insect Biochem Physiol. 2001;48:121-8.

39. Lange AB, Alim U, Vandersmissen HP, Mizoguchi A, Vanden Broeck J, Orchard I. The distribution and physiological effects of the myoinhibiting peptides in the kissing bug, rhodnius prolixus. Front Neurosci. 2012;6:98.

40. Simo L, Park Y. Neuropeptidergic control of the hindgut in the black-legged tick Ixodes scapularis. Int J Parasitol. 2014;44:819-26.

41. Szabo TM, Chen R, Goeritz ML, Maloney RT, Tang LS, Li L, et al. Distribution and physiological effects of B-type allatostatins (myoinhibitory peptides, MIPs) in the stomatogastric nervous system of the crab Cancer borealis. J Comp Neurol. 2011;519:2658-76.

42. Fu Q, Tang LS, Marder E, Li L. Mass spectrometric characterization and physiological actions of VPNDWAHFRGSWamide, a novel B type allatostatin in the crab, Cancer borealis. J Neurochem. 2007;101:1099-107.

43. Takahashi T, Muneoka Y, Lohmann J, Lopez De Haro MS, Solleder G, Bosch TC, et al. Systematic isolation of peptide signal molecules regulating development in hydra: LWamide and PW families. Proc Natl Acad Sci U S A. 1997:94:1241-6.

44. Takahashi T, Kobayakawa Y, Muneoka Y, Fujisawa Y, Mohri S, Hatta M, et al. Identification of a new member of the GLWamide peptide family: physiological activity and cellular localization in cnidarian polyps. Comp Biochem Physiol B Biochem Mol Biol. 2003:135:309-24.

45. Fredriksson $\mathrm{R}$, Schioth HB. The repertoire of G-protein-coupled receptors in fully sequenced genomes. Mol Pharmacol. 2005;67:1414-25.

46. Struck TH, Paul C, Hill N, Hartmann S, Hosel C, Kube M, et al. Phylogenomic analyses unravel annelid evolution. Nature. 2011;471:95-8.

47. Saulnier-Michel C. Polychaeta: Digestive System. In: Harrison FW, editor. Microscopic Anatomy of Invertebrates. Volume 7. New York, USA: Wiley-Liss, Inc; 1992. p. 53-69. [Harrison FW, Gardiner SL (Series Editor).

48. Tzetlin A, Purschke G. Pharynx and intestine. In: Bartolomaeus T, Purschke G, editors. Morphology, molecules, evolution and phylogeny in polychaeta and related taxa. Dordrecht, The Netherlands: Springer; 2005. p. 199-225.

49. Kitamoto $Y$, Yuan X, Wu Q, McCourt DW, Sadler JE. Enterokinase, the initiator of intestinal digestion, is a mosaic protease composed of a distinctive assortment of domains. Proc Natl Acad Sci U S A. 1994;91:7588-92.

50. Asadulina A, Panzera A, Veraszto C, Liebig C, Jekely G. Whole-body gene expression pattern registration in Platynereis larvae. Evodevo. 2012:3:27.

51. Conzelmann M, Williams EA, Krug K, Franz-Wachtel M, Macek B, Jekely G. The neuropeptide complement of the marine annelid Platynereis dumerilii. BMC Genomics. 2013;14:906.

52. Nesto N, Simonini R, Prevedelli D, Da Ros L. Effects of diet and density on growth, survival and gametogenesis of Hediste diversicolor (OF Muller, 1776) (Nereididae, Polychaeta). Aquaculture. 2012;362:1-9.

53. Bridges TS, Farrar JD, Gamble EV, Dillon TM. Intraspecific density effects in Nereis (Neanthes) arenaceodentata Moore (Polychaeta: Nereidae). J Exp Mar Biol Ecol. 1996;195:221-35.

54. Scaps P. Intraspecific agonistic behaviour in the polychaete Perinereis cultrifera (Grübe). Vie et milieu. 1995:45:123-8.

55. Miron G, Desrosiers G, Retiére C, Lambert R. Dispersion and prospecting behaviour of the polychaete Nereis virens (Sars) as a function of density. J Exp Mar Biol Ecol. 1991;145:65-77.

56. Gunawardene AR, Corfe BM, Staton CA. Classification and functions of enteroendocrine cells of the lower gastrointestinal tract. Int J Exp Pathol. 2011;92:219-31.

57. Marder E, Bucher D, Schulz DJ, Taylor AL. Invertebrate central pattern generation moves along. Curr Biol. 2005;15:R685-99.

58. Olive PJW. Polychaete aquaculture and polychaete science: a mutual synergism. Hydrobiologia. 1999;402:175-83.

59. Qian PY, Chia FS. Larval Development as Influenced by Food Limitation in 2 Polychaetes - Capitella Sp and Polydora-Ligni Webster. J Exp Mar Biol Ecol. 1993;166:93-105.

60. Pawlik JR, Mense DJ. Larval transport, food limitation, ontogenetic plasticity, and the recruitment of sabellariid polychaetes. In: Wilson JWH, Stricker SA, Shinn GL, editors. Reproduction and Development of Marine Invertebrates. Baltimore, Maryland: John Hopkins University Press; 1994. p. 275-86.

61. Qian PY, Pechenik JA. Effects of larval starvation and delayed metamorphosis on juvenile survival and growth of the tube-dwelling polychaete Hydroides elegans (Haswell). J Exp Mar Biol Ecol. 1998;227:169-85.
62. McEdward LR, Qian PY. Effects of the duration and timing of starvation during larval life on the metamorphosis and initial juvenile size of the polychaete Hydroides elegans (Haswell). J Exp Mar Biol Ecol. 2001;261:185-97.

63. Li W, Godzik A. Cd-hit: a fast program for clustering and comparing large sets of protein or nucleotide sequences. Bioinformatics. 2006;22:1658-9.

64. Castresana J. Selection of conserved blocks from multiple alignments for their use in phylogenetic analysis. Mol Biol Evol. 2000;17:540-52.

65. Guindon S, Dufayard JF, Lefort V, Anisimova M, Hordijk W, Gascuel O. New algorithms and methods to estimate maximum-likelihood phylogenies: assessing the performance of PhyML 3.0. Syst Biol. 2010;59:307-21.

66. Degnan BM, Groppe JC, Morse DE. Chymotrypsin Messenger-Rna Expression in Digestive Gland Amebocytes - Cell Specification Occurs Prior to Metamorphosis and Gut Morphogenesis in the Gastropod, Haliotis-Rufescens. Rouxs Archives of Developmental Biology. 1995;205:97-101.

67. Conzelmann M, Jekely G. Antibodies against conserved amidated neuropeptide epitopes enrich the comparative neurobiology toolbox. Evodevo. 2012;3:23.

68. Staudt T, Lang MC, Medda R, Engelhardt J, Hell SW. 2,2'-thiodiethanol: a new water soluble mounting medium for high resolution optical microscopy. Microsc Res Tech. 2007;70:1-9.

69. Chen TW, Wardill TJ, Sun Y, Pulver SR, Renninger SL, Baohan A, et al. Ultrasensitive fluorescent proteins for imaging neuronal activity. Nature. 2013;499:295-300.

70. Randel N, Asadulina A, Bezares-Calderon LA, Veraszto C, Williams EA, Conzelmann $\mathrm{M}$, et al. Neuronal connectome of a sensory-motor circuit for visual navigation. Elife. 2014;e02730

71. Klopfenstein DR, Vale RD. The lipid binding pleckstrin homology domain in UNC-104 kinesin is necessary for synaptic vesicle transport in Caenorhabditis elegans. Mol Biol Cell. 2004;15:3729-39.

\section{Submit your next manuscript to BioMed Central and take full advantage of:}

- Convenient online submission

- Thorough peer review

- No space constraints or color figure charges

- Immediate publication on acceptance

- Inclusion in PubMed, CAS, Scopus and Google Scholar

- Research which is freely available for redistribution 